\title{
Stratigraphic ANalysis of the Aratu Stage (Lower Cretaceous), RecônCaVo BASIN (BRAZIL), WITH HYDROCARBON RESERVOIR ROCKS
}

\author{
Jorge Carlos Della Fávera ${ }^{1}$, Hernani Aquini Fernandes Chaves ${ }^{1 *}$, Marco André Malmann Medeiros ${ }^{1}$, Jorge \\ Tiago Lancates Villares ${ }^{1}$, Sheila Fabiana Marcelino de Souza ${ }^{1}$, Siana SoARes de Oliveira ${ }^{1}$ AND MaRia Virginia \\ ALVES MARTINS ${ }^{1,2}$
}

1. Universidade do Estado do Rio de Janeiro - UERJ, Faculdade de Geologia, Departamento de Paleontologia e Estratigrafia, Av. São Francisco Xavier, 524, Maracanã. 9 CEP 20550-013, Rio de Janeiro, RJ, Brazil.

2 Universidade de Aveiro, Departamento de Geociências, GeoBioTec, Aveiro, Portugal

* Corresponding AUTHor, hafchaves@gmail.com

Received on 2 May 2019

Received in revised form on 20 June 2019

Accepted on 22 June 2019

Editor: Maria Antonieta da Conceição Rodrigues, Universidade do Estado do Rio de Janeiro
Citation:

Della Fávera, J.C., Chaves, H.A.F., Medeiros, M.A.M., Villares, J.T.L., Souza, S.F.M., Oliveira, S.S., Alves Martins, M.V., 2019. Stratigraphic analysis of the Aratu Stage (Lower Cretaceous), Recôncavo Basin (Brazil), with hydrocarbon reservoir rocks. Journal of Sedimentary Environments, 4 (2): 199-219.

\section{Abstract}

The section between the 7 and 11 electric markers in the Aratu Stage of the Recôncavo Basin (Lower Cretaceous) has been studied in order to perform a stratigraphic analysis. This section bear reservoir rocks known as Imbé, Cambuqui and Miranga sandstones. It produces petroleum in fields like Miranga, Araçás, Taquipe, Miranga Norte and Imbé.

The isopach map showed a general trend of increased subsidence for south and southeast. A series of structural lows surround the platform region known as Quiricó High. Southwestward, the Taquipe Canyon is an indication of the lake deepening in that region.

In terms of depositional systems, it was interpreted that the Aratu Stage presented a river-dominated deltaic system all over its depositional history. In the proximal regions, located to the north and northwest, the main facies belong to the fluvial and delta plain associations and to the delta front and prodelta in the most distal system. The isolithic map and the sand percentage map indicates a main axial sand distribution. The main sedimentary inflow comes from north and northwest. Near the southeastern faulted border there is a slight contribution from the alluvial fans attached to the Salvador fault.

\section{Introduction}

The Recôncavo Basin, explored since the 1930s, is an extremely prolific oil basin (Figueiredo et al., 1994). It is currently in the mature phase of exploration for hydrocarbons, but the network of available production and transportation facilities also allows the pursuit of targets involving relatively small volumes of oil. The availability of geological data makes it a quintessential basin.

Aratu Stage exhibits a high volume of hydrocarbons in the fields of Miranga and Araçás, in addition to other smaller
As a natural consequence, the stratigraphic sections showed a decrease of sand south and southeastward as well as the Spontaneous Potential (SP) logs indicate a progressive change from fluvial (normal bell shapes) to deltaic patterns (inverted bell shapes).

The sedimentary cyclicity is strongly depicted in the Aratu section. Part of it can be observed in resistivity and SP logs, where autocorrelation can be obtained. Peaks in the resistivity logs indicate lag deposits due to periodic lake flooding. The resistivity value, as a function of the thickness of ostracodal and fish remains calciferous sandstones and shales, allows to separate several orders of peaks (four to six orders). Conventional cyclicity analyses indicate clearly an orbital control due to precession and axial obliquity. The calculated sedimentation ratio is $60 \mathrm{~cm} / 1000$ years, and the time interval of $1.44 \mathrm{Ma}$ for deposition of the entire section.

Keywords: Oil Exploration. Isopach Map. Isolithic Map. Resistivity Logs. Cyclicity Analyses. Orbital Control. Depositional Systems. River-Dominated Deltaic System.

fields (Figueiredo et al., 1994). The nature of its sedimentary section, which in much of the basin comprises the Pojuca Formation, facilitates the geological interpretation, since it is characterized by the cyclicity of several orders of magnitude; the consequence of this, is the repetition of sedimentary facies that seems to have been connected to shallow marine water.

This work aims to perform a stratigraphic analysis of the Marker 7 to Marker 11 bed interval of the Aratu Stage of the 
Recôncavo Basin (Lower Cretaceous) (Figs. 1, 2 and 3). It is based on the study of petrophysical profiles of the Recôncavo Basin, mostly containing spontaneous potential (SP) and resistivity (RILD) curves, which were used to correlate mappable intervals. At the same time, well cores described and illustrated in the work of Horschutz et al. (1973), were re-described and analyzed. This information plus fieldwork in the Recôncavo Basin, in which sedimentary facies similar to the mentioned interval were studied, allowed to elaborate a stratigraphic analysis compatible with the time available for the study.

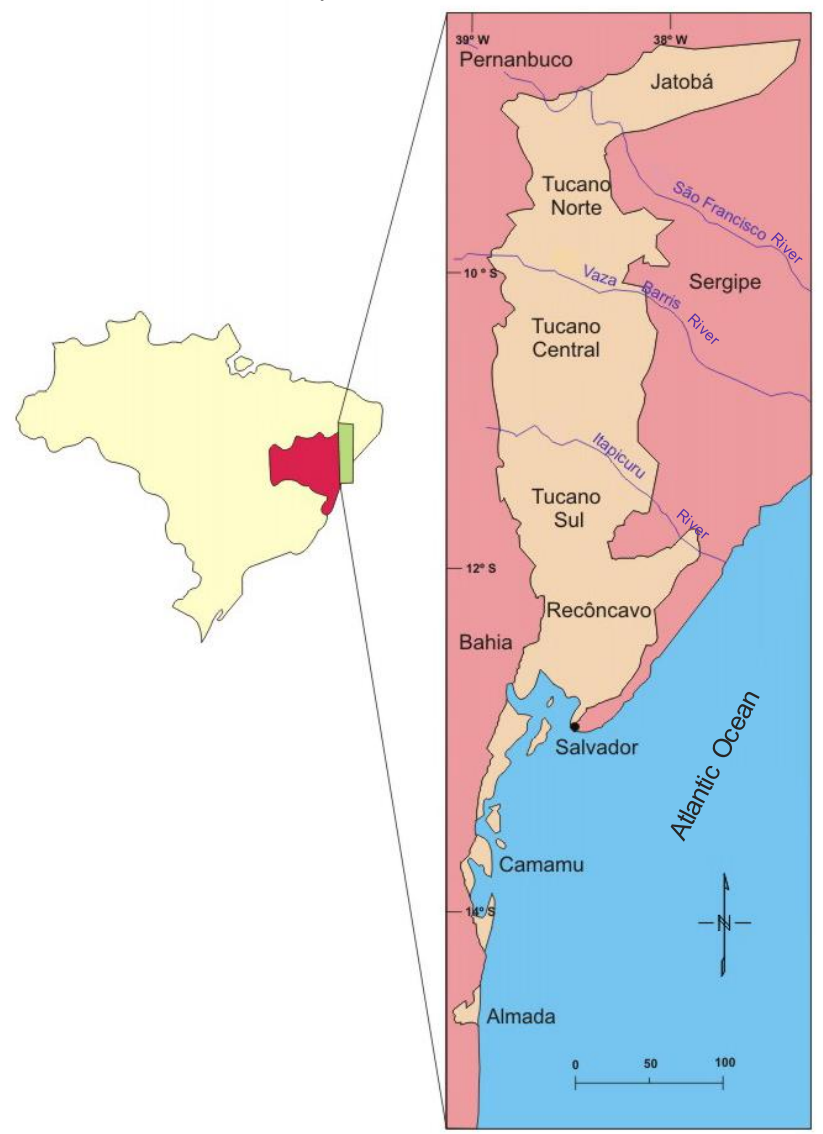

Fig. 1. Location map of the Recôncavo Basin.

\section{Study Area}

\subsection{The rift phase and its importance in the development of the Brazilian Continental Margin}

The sialic mass accumulated during the formation of the supercontinent Pangea started at the beginning of the Cretaceous (Bozhko, 2009). To the south of the Cumuruxatiba basin, because the continental crust was less thick, there was invasion of basaltic lava that filled the first depressions of this primitive fracturing (Ferreira et al., 2014). To the north, however, the crust, being thicker, prevented the basaltic effluvium and the basins evolved simply as a terrigenous-, and later, evaporites- and carbonates- fill basin.

To northeast, the Recôncavo, Tucano and Jatobá Basins, which constituted a system of fractures predominantly NE-
RESEARCH PAPER

SW, limited a micro-plate, whose outer border were the fractures that limited the rifts of the current continental margin (Gordon et al., 2017). The microplate turned in an anti-clockwise direction, producing compression deformations even in the equatorial margin, Ceará coast (Szatmari, verbal information). However, this rift system did not evolve into an ocean, such as the adjacent marginal system. It was aborted even before the beginning of the Alagoas Stage, although its completion has been remarkable.

The Recôncavo Basin exhibits a sedimentary column that reaches seven thousand meters in thickness, formed exclusively by terrigenous sediments (Ferreira et al., 2014). The faulted margin of the basin exhibits a conglomerate wrap that exceeds five kilometers in width. The other margin, called flexural, is, however, responsible for filling the basin.

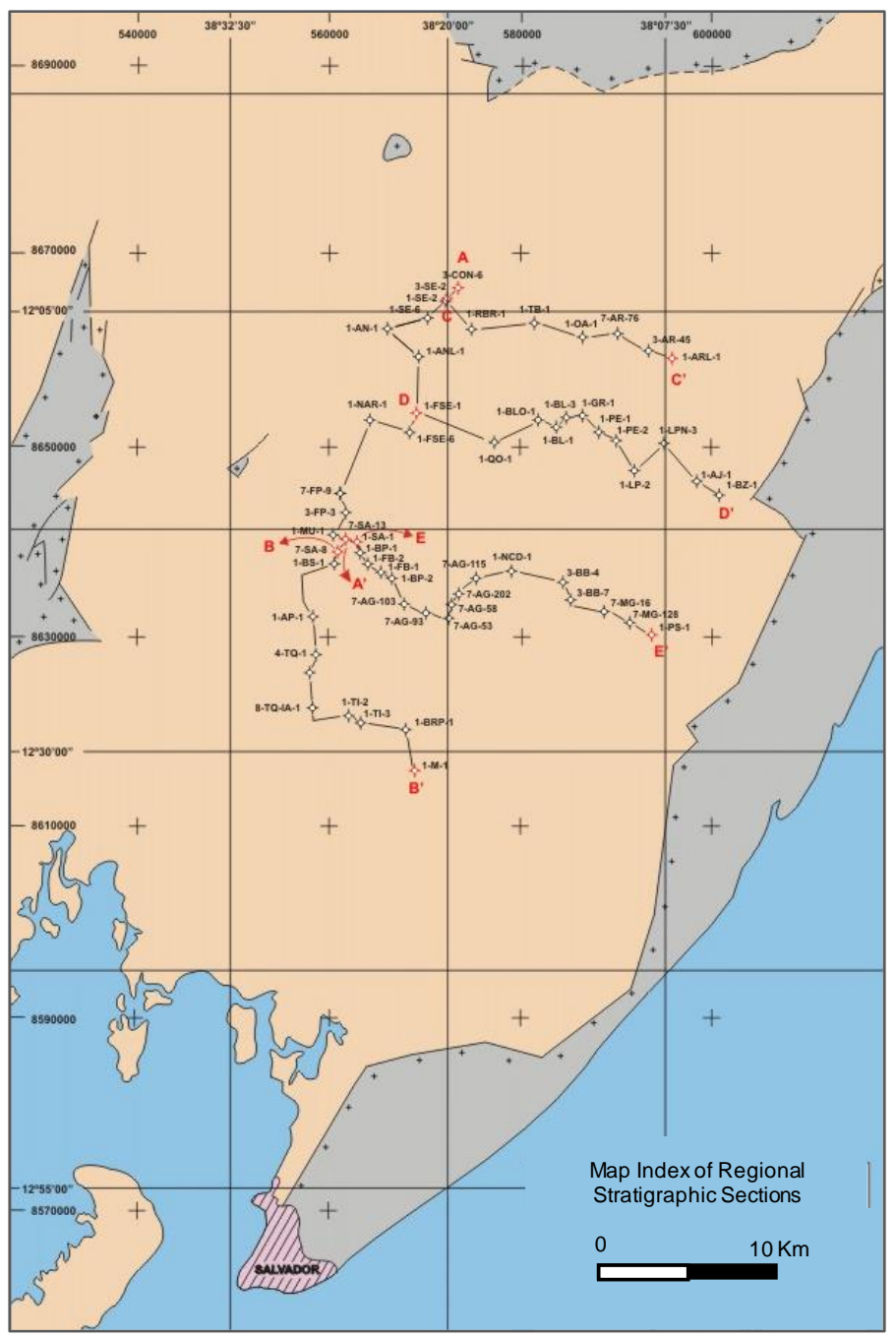

Fig. 2. Location map of wells and sections

The Recôncavo Basin exhibits the conformation of a classic rift or Gregory rift (Gregory 1896, 1921) with dimensions similar to modern African lakes: $60 \mathrm{~km}$ wide versus approximately $100 \mathrm{~km}$. The fracture evolved from a central crevice that progressively expanded to the periphery. 


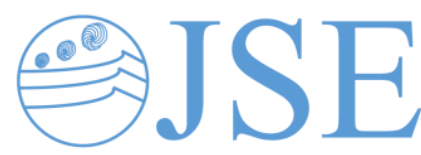

RESEARCH PAPER

In this way, the thick packet of faulted margin conglomerates exhibits a vertically transgressive trend.

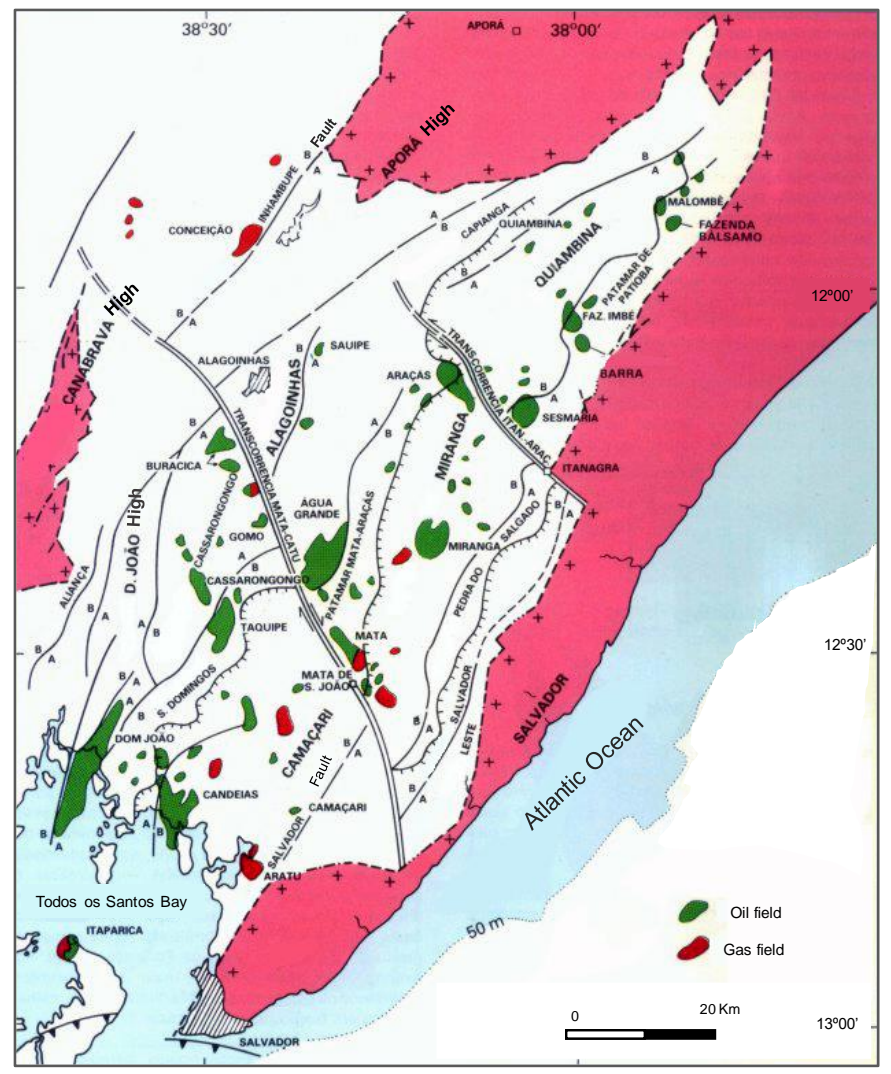

Fig. 3. Map with the Recôncavo fields.

\subsection{Tectonosedimentary Evolution}

The Recôncavo Basin, together with the Tucano and Jatobá basins, occupies an area of approximately $30,000 \mathrm{~km}^{2}$. It is located northeast of Bahia and south of Pernambuco states, and composes the southern portion of the Recôncavo-Tucano-Jatobá Intracontinental Rift (Fig. 3). Its occurrence and evolution are directly related to the extensional processes that culminated in the break of the Gondwana Super Continent, and consequently to the initial stages of the opening of the Atlantic Ocean (Neocomian/Lower Cretaceous) (Milani, 1987).

During the Jurassic period, subsidence of the basin occurred through a crustal flexure, inherent to the elastic deformation phase. After the limit of elastic resistance, the crust ruptured, originating the rift. Before rifting, there was a long period characterized by a small subsidence rate, which allowed the development of a basin with intracratonic characteristics, called the "Afro-Brazilian depression" (Asmus and Ponte, 1973; Asmus and Porto, 1980; Fernandes Filho et al., 1952).

Thus, the Recôncavo-Tucano-Jatobá Rift represents the ramification that was orientated along the western line of the main lineament of rifts that generated the South Atlantic
Ocean, which failed, generating an aborted arm that prevented the total rupture of the crust under the rift (Milani, 1987). This prevented the formation of oceanic crust, providing a favorable environment for the marine sedimentation that occurred in the marginal marine basins.

The presence of shale diapirism along the reservoirs of the Recôncavo Basin, mainly in the central and southern portions of the basin, is also observed in the rift phase (Milani, 1987). The diapiric clays are from Rio da Serra Stage (4.1), which were destabilized by thick packets of fine sandy sediments as well as wedges of conglomerates and other thick clastic materials of the eastern edge of the basin.

In the middle Aratu Stage, there are growth faults and lower areas in the southern portion of the basin, where the Taquipe Canyon was developed, eroding the sediments of Aratu Inferior and Rio da Serra Superior stages. Later, this canyon was filled by shale, marl, limestone and turbiditic sandstones (Taquipe Formation), covered by delta sediments (Pojuca Formation) (Figueiredo et al., 1994).

At the beginning of the Buracica age, the final sedimentation of the basin (São Sebastião Formation) begins, concomitantly with the beginning of tectonic activity in the system of transcurrent faults oriented according to the occurred until the end of the Jequiá age, were responsible for the compartmentalization of the basin (Magnavita, et al., 2005).

The post-rift subsidence phase began with the removal of the basin from the heat source, due to the separation of the continents, and was more pronounced in the SE portion of the basin (Ponte et al., 1971). At this stage, due to a low subsidence rate, favorable conditions are present for the deposition of the fluvial sediments of the Marizal Formation. In the final stage of sedimentation (Miocene), the basin is invaded by the sea, and is characterized by the deposition of the Sabiá Formation (Pliocene) (Figueiredo et al., 1994).

Della Fávera et al. (1994a) proposed an evolution model for the Pendent rift in the Potiguar Basin, composed of three distinct phases: the initial phase of deep lake, followed by a shallow lake phase, and finally by a silted lake. The same happened in Recôncavo Basin.

The initial phase, corresponding to the Candeias Formation, Member Gomo, corresponded to a deep lake (Picarelli and Abreu, 2012), similar to the modern lakes of Malawi (800 $\mathrm{m}$ deep) and Tanganyika (1500 m deep) of East Africa. At this stage, gravitational flow deposits from marginal and internal fault escarpments to the tectonic lake predominate. The filling of this phase is predominantly clayey, quite organic, enclosing sandstones and conglomerates formed by streams of detritus and associated turbidity currents.

With the high sedimentation rate found in the rift, the lake became progressively shallower. Sedimentation became dominated by rivers and is characteristically deltaic. As observed in modern tectonic lakes, these deltas have a webdirection $\mathrm{N} 40^{\circ} \mathrm{W}$. The horizontal displacements, which 
shaped conformation whose distributaries advance inwards toward the lakes, with pronounced marginal dikes. The transition between deep lake and shallow lake occurs in the younger portion of Rio da Serra Stage, a situation in which the delta front was influenced by small channels (delta-front troughs, according to Klein et al., 1972), when it formed the so-called slurry flows, forming the Pitanga sandstones. The characteristic delta phase begins in the sandstones of the Marfim Formation and extends to the middle of the Buracica Stage (São Sebastião Formation). It is at this stage that lutokinetic uplift of clayey masses of the prodelta also occurs.

In this work, the studied interval belongs to Aratu Stage and illustrates a typically deltaic phase. From the Pojuca Formation to the end of the rift phase, a tectonic quiescence predominates, where the movements of blocks of faults occur almost exclusively on the faulted edge. It is also at this phase that an important contribution of lake eustasy to the distribution of sediment types is observed. These eustatic movements, which in modern lakes have rates approximately $100 \mathrm{~m} / 1,000$ years, have shown an exceptional sedimentary cyclicity. The tectonic quiescence is exemplarily demonstrated by the wells located next to clay diapirs, in peripheral synclines. In these regions, due to the high subsidence rate produced by the lifting of the diapir, due to sinking of its periphery, there is always enough space for deposition. Erosion is restricted to some river components. The thickness is almost always more than twice the section outside the area of the diapir. In these places, the electric markers, notable for their constancy, appear as if the section were stretched as an elastic (see Fig. 4, stratigraphic reference profile). Due to the absence of erosion, transgressive lags (residual deposits), observed in several orders of magnitude, and eustatic growth of the lake, are exceptionally preserved.

At the beginning of the Rio da Serra Stage, the basin underwent a deep phase, which was followed by a period of shallowing with recurrence of the fluvial system and eolian rework, in a tectonically stable phase (Figueiredo et al., 1994). The development of this fluvial-eolian system, prograding from north to south, marks a change in the source areas of the basin, which until then were situated to the south and the west.

The increase of the sedimentation rate, associated with a sudden climatic change, created conditions for the resumption of the lacustrine system in the basin, this time anoxic, giving rise to the gray-dark shales (Tauá Member of the Candeias Formation) (Picarelli and Abreu, 2012). The final deposition of these sediments marks the beginning of the rift phase. The distensive efforts, characteristic of this phase, generated normal faults of high angle and predominant direction $\mathrm{N} 30^{\circ} \mathrm{E}$, originating, therefore, tectonic cavities where deep lakes developed.

During the rift phase, the Gomo Member is deposited, initially in a restricted lake that is later enlarged and deepened during the sedimentation of the Maracangalha Formation (Picarelli and Abreu, 2012). In addition, throughout the rift phase, syntectonic alluvial fans are formed next to the east edge fault system.

What would be the depth of this lake? There is almost a consensus that it would have been shallow, due to the facies found, mainly sigmoidal lobes. Just to the south of the basin, due to the predominance of clays and the disappearance of marker beds, it is interpreted as having been deeper. The same happens in the flexural border, where the so-called "Taquipe Canyon" develops (Figueiredo et al., 1994). whose excavation took place near the Marker 7 bed. In this canyon, the marker beds do not develop and facies similar to those of the Pitanga Formation occur.

The shallow lake phase transitions to that of a silted lake. This condition is seen in the upper section, Buracica Stage, where the percentage of sand is high.

The rift phase ends at the Jiquiá Stage. Then a new postrift tectonic pulse emerges, which, like elsewhere in the world, changes the structuring previously established (Figueiredo et al., 1994). The new sedimentary cycle, in Alagoas Stage, no longer exhibits the sedimentary characteristics of the rift phase, and is notable due to the occurrence of evaporites.

\subsection{Stratigraphy of the Reconcavo Basin}

The stratigraphic concepts in the Recôncavo Basin evolved strongly since it is a highly prolific basin (Fig. 5).

The use of the stratigraphic nomenclature code for this basin was quite heterodox. Since the Recôncavo was a strongly structured basin, emphasis was given to both surface and subsurface mappings, and to biostratigraphic aspects (in their chronostratigraphic character), leaving lithostratigraphic aspects as secondary. Thus, "formations" were characterized not by their lithological aspects, but by biotic content (ostracods and pollen). With this, the task of visualizing structural traps was favored, since these depended on chronostratigraphic reference horizons (biozones or petrophysical marker beds) for the relative establishment of high or low blocks. The seismic surveys also worked in the same way, since today it is known that seismic reflectors basically mark time lines or geologic discontinuities, which, by nature, have a chronostratigraphic character. This allowed, for example, exploratory leases based on a structural map of Marker 11 bed, irrespective of which lithostratigraphic units this landmark might belong to.

The situation persisted until the early 1970s, when a new stratigraphic code was developed. This time, geological characteristics justified its use, however, it led to the wrong evolutionary model. Due to the influence of foreign consultants, who imported models from the Gulf of Mexico coast, it was proposed that the basin was a lake progressively filled by a protuberant fluvio-deltaic system, producing a giant offlap. All units, according to this model, would be 


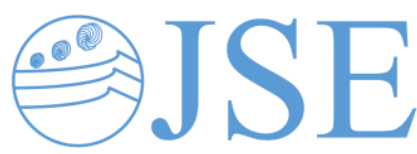

RESEARCH PAPER

genetically related. The ostracod biozones would mark earlier paleoecological situations rather than a temporal evolution. The petrophysical milestones, well accepted since the 1950s, and parallel to the biozones, were considered diachronous, cutting offlap time lines. Thus, the stratigraphy of the basin suffered an involution. This situation lasted until
1985, when the old concepts were reestablished after a long campaign of persuasion. This idea was later reinforced by Rossetti's work in the Potiguar Basin (Rossetti, 1996), which seismically showed that there is progression in the rift, but this occurs only in small intervals, separated by lake-level fluctuation events.

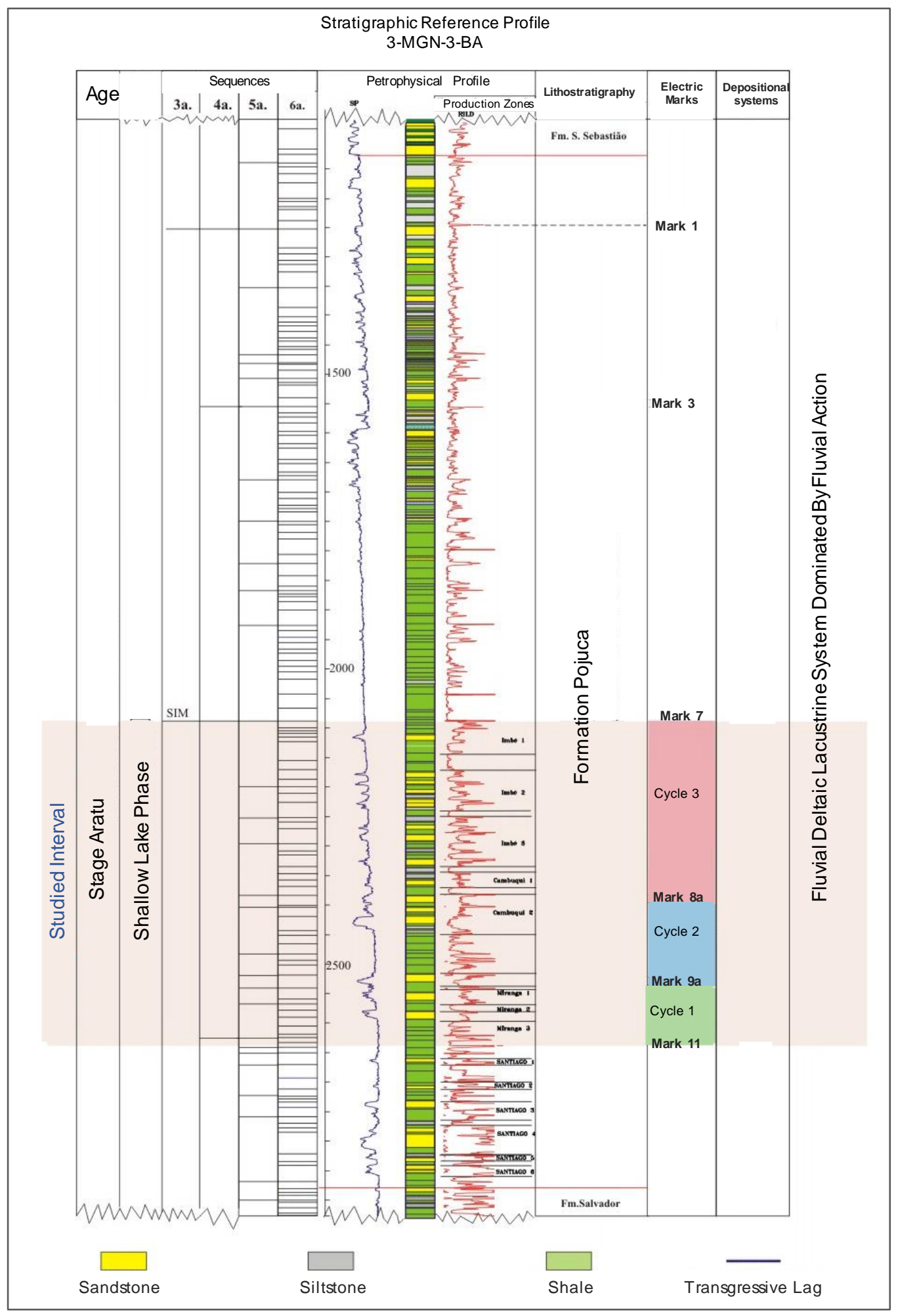

Fig. 4. Stratigraphic Reference Section. 


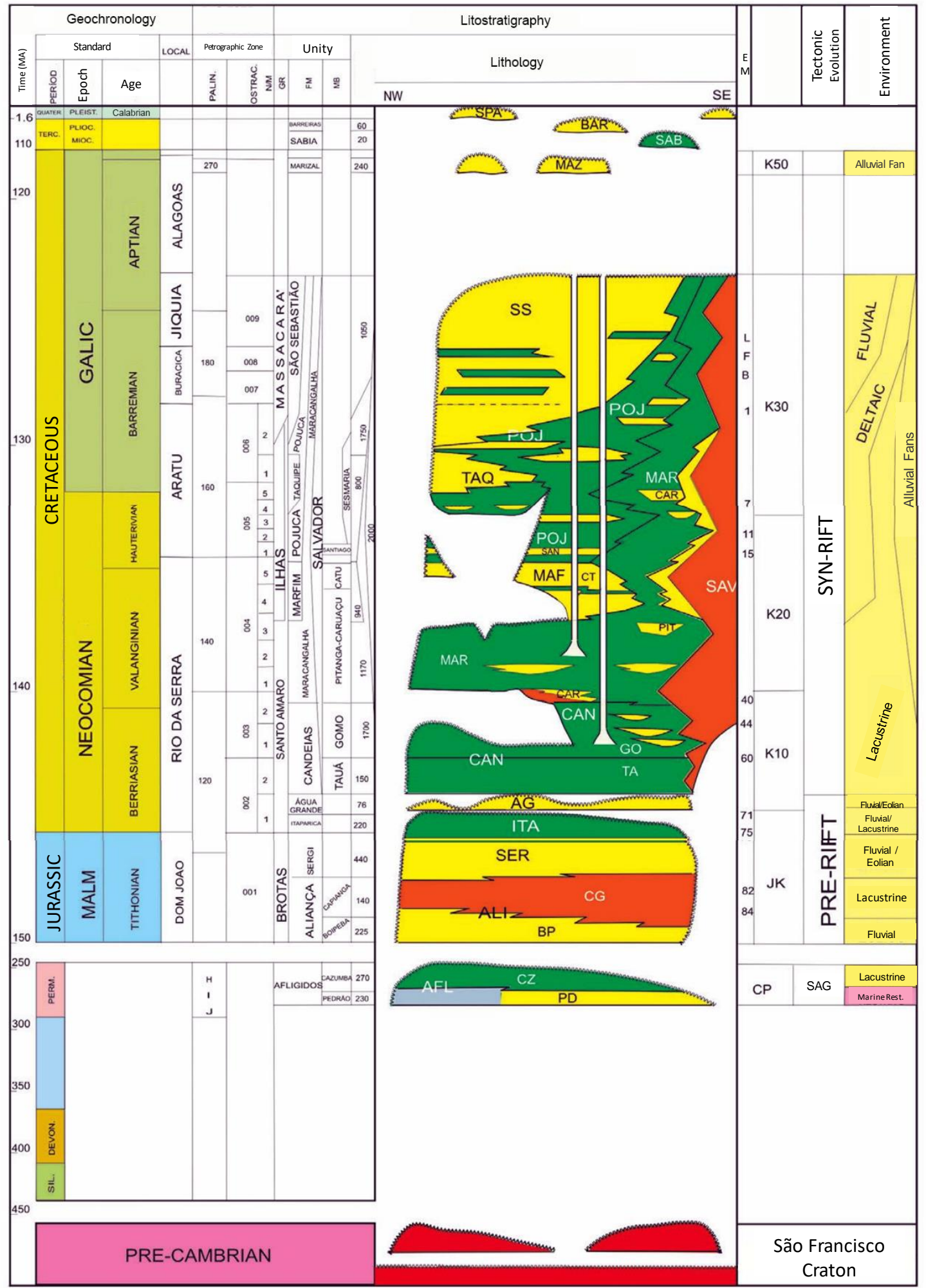

Fig. 5. Stratigraphic column of the Recôncavo Basin (adapted from Caixeta et al., 1994).

\section{Materials and Methods}

In this work was applied the same method used in the Laboratory of Basin Analysis and Geological Correlation (LABCG) of the State University of Rio de Janeiro to characterize the stratigraphic analyzes of the sedimentary basins.

This study is based on a frame of oil wells of the Recôncavo Basin, arranged in five stratigraphic sections, two in the direction of the layers (strike-NE-SW) and 


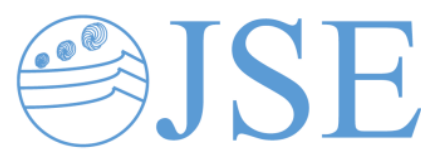

RESEARCH PAPER

three in the depositional dip (NW-SE). The interval between Marker 7 bed and Marker 11 bed was detailed for the insertion of other electric marker beds $(8,8 \mathrm{a}, 9$ and 9 a). The intervals, delimited by these lesser marker beds, had their bodies of sandstone and siltite counted, computing a sandstone-shale ratio that was mapped at each interval.

The purpose of these maps was to indicate the main source of the sediments and to point out the sites of sand accumulation. Based on the distribution of the sands in these maps, the depositional system present in each interval was delineated. The lateral variation of the sand bodies was emphasized by the construction of the stratigraphic sections. The interpretation of the depositional system was greatly facilitated by the interpretation of the description of well cores and outcrops in the field, accompanied by previous interpretations, as reported in the literature (Fig. 5).

\subsection{Previous Works}

For the present study, two previous studies were considered, from which the conclusions are drawn:

Horschutz et al. (1973) studied the delta sedimentation of the Cambuqui sequence, Pojuca Formation, in the Recôncavo Basin, using petrophysical profiles, mainly the Spontaneous Potential (SP) and resistivity (RILD) curves in association with the survey data available at the time.

Potter et al. (1977) studied the deposition of the Buracica / Jiquiá stages, based on geophysical profiles of wells, samples and outcrops of the Recôncavo Basin, in a training project for new Petrobras geologists. They made considerations about the sedimentary facies and petrography of sandstones, concluding on their origin. They admit a fluvial-lacustrine deposition, mainly by meandering rivers.

Silva (1993) proposed the division of the rift phase into six tectonodepositional intervals. He used the procedure formulated by Galloway (1989), that is, that of the genetic depositional sequences, which differs from that proposed by the Exxon research group (Vail, 1987; Van Wagoner et al, 1987): whereas Exxon defended limits at discontinuities, Galloway placed the limits at the maximum flooding surface.

The two older tectonodepositional intervals are related, except for the Água Grande unit, to the deep lake phase (Della Fávera et al., 1993). Interval III corresponds to the Caruaçu and Marfim formations, fluvio-deltaic units, although the Caruaçu Formation still contains deepwater facies resulting from delta front slides and respective gravitational flows. Interval IV coincides with the lower portion of the Aratu Stage, bounded by Marker 7 bed at the top and Marker 15 bed at the base (Fig. 4). This interval contains the section presently studied in the project, that is, the portion between Markers 7 and 11 .
The two upper intervals coincide, respectively, with the top of the Aratu Stage, between Marker beds 1 and 7, and the Buracica and Jiquiá Stages.

Although based on the establishment of distinct boundaries, the Galloway (1989) and Exxon (Vail, 1987; Van Wagoner et al, 1987) methodology do not conflict. In lacustrine tectonic basins, limits established by discontinuities are difficult to mark, since these discontinuities are often limited to isolated, tectonically elevated blocks, along with other blocks that have not been eroded. A relatively easy method would be to use dipmeter profiles, which may show different attitudes of the layers above and below a discontinuity surface, although at times it is a simple fault. Unfortunately, we do not have access to such data, which, however, are abundant in the Recôncavo Basin. The stratigraphic treatment given in this work uses the Galloway (1989) method because it is simpler, avoiding complicated definitions of dislocations.

\section{Results and Discussion}

\subsection{Tectonodepositional intervals of the Reconcavo Basin}

\subsubsection{Third-Order Sequences of the Aratu Stage}

Third-order sequences were defined by Vail et al. (1991), as those that have a duration between 800 thousand and three million years. These temporal values would be different in a rift stage, where subsidence is very strong, especially in depocenters located in peripheral synclines of clay diapirs (Fig. 4). For this reason, we consider as third-order sequences the same tectonodepositional intervals as above. Thus, in the Aratu Stage, there would be two third-order sequences: one basal, limited by Marker beds 15 and 7, and one higher, between Marker beds 7 and 1. All these petrophysical maker beds are easily recognizable in the analyzed well profiles.

\subsubsection{Fourth-Order sequences of The Aratu Stage}

Using the same procedure as in marking third-order sequences, the fourth-order ones also had flooding surfaces as limits. As can be seen in Fig. 4, the oldest sequence has the characteristic of hosting the interval known as Santiago, one of the main producers of the Recôncavo. If the Exxon criterion was used to delimit sequences, this sequence would be limited at the Santiago sandstone base 6, above Marker 14, which is not marked in the stratigraphic reference profile.

The next sequence is limited at the base by Marker 11 bed and at the top by the Marker 7 bed. This interval is the one studied in the present project, containing sandstones Imbé 1, 2 and 3, sandstones Cambuqui 1 and 2, and sandstones Miranga 1, 2, and 3. 


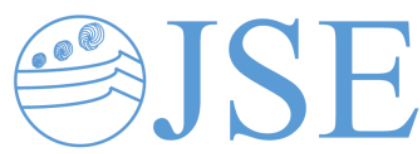

RESEARCH PAPER

\subsubsection{Fifth-Order Sequences of Aratu Stage}

By the criterion of sandstone or calciferous shale peaks, which mark transgressive lags, 30 fifth-order sequences were recognized in Aratu. However, because the marking of these transgressive lags was done in a well profile located in an area of great subsidence, almost without erosion, in platform areas, the absence of this large number of sequences is justified, where intense river erosion processes predominated. In addition, by observing the thickness variation in Fig. 4, it can be deduced that the subsidence rate increases towards the top, since these sequences exhibit an increase in thickness as one goes up in the section.

\subsubsection{Sixth-Order Sequences of Aratu Stage}

By using smaller peaks, which means a smaller thickness of the transgressive lags, one reaches 133 sixthorder intervals. It is interesting to note that the preservation of these intervals is due exclusively to the subsidence behavior in the region of well 3-MGN-3-BA. Variations of the "worm path" type, common in profiles of cyclicity analysis, are quite common. Observing sandstone occurrence intervals, the limits of these intervals occur between sandstones.

\subsection{Depositional Facies and Systems}

The depositional systems involved in the Pojuca Formation are, most of the time, related to a shallow lake and to river systems that entered the basin, building lacustrine deltas. Thus, sandstone deposits represent systems ranging from the meandering fluvial, or eventually interlaced, in more arid times, through crevasse-splay-like constructions and, finally, deltas. The major controls of this type of deposit are, in order of importance, tectonic and lacustrine eustasy, the latter, in turn, controlled by climate. At the faulted edge of the basin, fault escarpments or fault lines likely control the formation of alluvial fans, which extended over the duration of sedimentation.

\subsubsection{Fluvial Systems}

The ubiquity of sandstones at certain stratigraphic intervals in the basin has already led geologists to think in a layer-cake scheme. This type of reasoning served to justify, later on, another absurdity, which was the total contempt for the indications of depositional surfaces or time surfaces (timelines), in which petrophysical landmarks and tops of biostratigraphic zones would fit, without considering seismic reflections, which are in themselves enlightening. However, Rossetti (1996) and Soares and Rossetti et al. (2005) demonstrated that, in the Potiguar Basin rift, relatively thin sandstones of regional extension are the product of very rapid progression of fluvio-deltaic systems.
The Imbé, Cambuqui and Miranga sandstones, which are in the studied interval, exhibit fluvio-deltaic facies. The cores that illustrate this monograph, cut in well 3-MG-99BA (Fig. 6), are good examples of a meandering river system. As an easy indication of the presence of these fluvial systems, it is enough to observe the curves of the spontaneous Potential Profiles (SP), which are of the "normal" type (Saitta-Bertoni and Visher, 1968). Marginal dykes, which separate point bar or river channel areas of the flood plain are characterized by the abundance of climbing ripples or ripple drift. Floodplains, by their nature, essentially clayey, when dried, become paleosols, which exhibit singular characteristics, such as fracturing type, and the presence of plant roots (Fig. 7). These characteristics are found in the core of well 3-MG-99-BA.

It is assumed that in arid times, there was a significant lowering in the level of the lake, as in the case of East Africa. On these occasions, due to floods or catastrophic floods, water would flow through a network of intertwined channels, in a wide alluvial plain, as occurs in Buracica Stage (Della Fávera et al. (1994b). These bodies have "box" type profiles and can be recognized in platform areas.

In times of great rainfall, due to the rise of the lake level, the rivers are unable to transfer their load to the mouth, throwing it instead into the floodplain, in the form of crevasse-splays. These splays are organized as deltas, forming sigmoid lobes.

\subsubsection{Deltaic Facies}

The prevailing concept regarding the sedimentation of the Reconcavo Basin was that it was the result of a lake delta entirely dominated by the action of the rivers. This type of delta had an important participation in the generation of subaquatic gravitational flows that were the main processes of accumulation of sediments in deep portions of the lake. In the shallow lagoon phase, riverdominated deltas participate with their main subenvironments: the delta plain, the delta front, and the prodelta.

\section{Delta Plain}

In a delta plain of a lacustrine delta, fluvial processes prevail, and it is even difficult to separate them from the plain due to the great dynamics that the lake level suffers. A large lowering of this level, which occurs during a periodic drought, causes the river systems to advance almost to the end of the basin. Thus, deltaic plain and river systems can be treated as a single item, without the need to distinguish the beginning of the distributary canal and head of passes, which do not have characteristic sedimentary features. The core from well 3-MG-99-BA, shown in Fig. 6 is a typical fluvial deposit. 


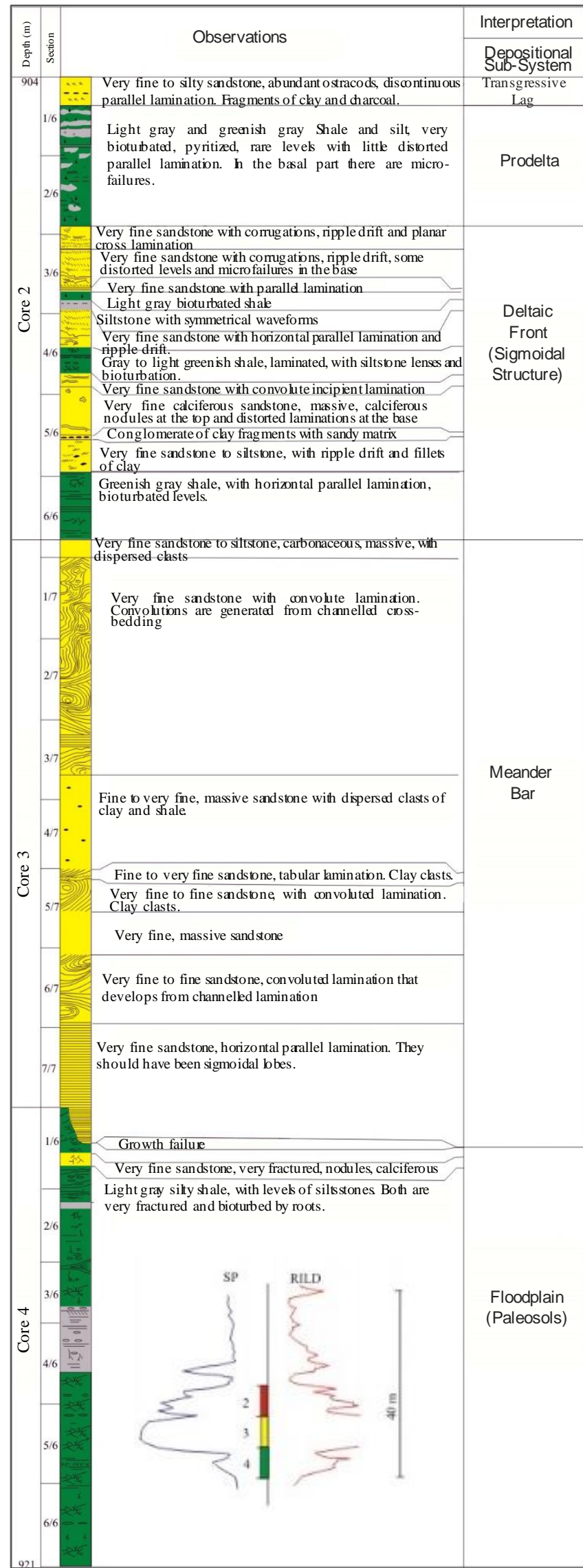

Fig. 6. Description of the sediments of the well 3MG-99-BA.

\section{Deltaic Front}

In deltas of the Pojuca Formation, as well as those of the São Sebastião Formation, it is difficult to apply the delta model, which was developed for the Mississippi Delta. Deltas of the Pojuca Formation were documented by Della Fávera (2001) and consist of a mouth bar, whose proximal portion is called the bar crest, exhibiting fluvial processes, followed by a surrounding semilunar shape of the so-called bar slope. The stacking of these two portions, which starts with prodeltaic deposits, generates an inverted bell-like curve (coarsening upwards and thickening upwards). The reference profile, as well as those of the stratigraphic sections, show many examples that suggest this type of curve.

On the other hand, the local reality, seen in the fronts and deltaic outcrops in Buracica Stage, in Tucano Basin, is composed of features known as sigmoidal lobes (Della Fávera et al. 1994b; Della Fávera, 2001). In Recôncavo, these features only appear on the Pojuca-Mata de São João highway (apparently the only outcrop of the Aratu Stage in the Recôncavo Basin). In the Tucano Basin, they occur in greater abundance, in the Buracica Stage. These sigmoidal lobes form a sandstone with a blocky pattern in the SP log. On the other hand, they have excellent reservoir characteristics. The association of sigmoids with climbing ripples or ripple drift is a characteristic of sigmoid lobes (Fig. 8).

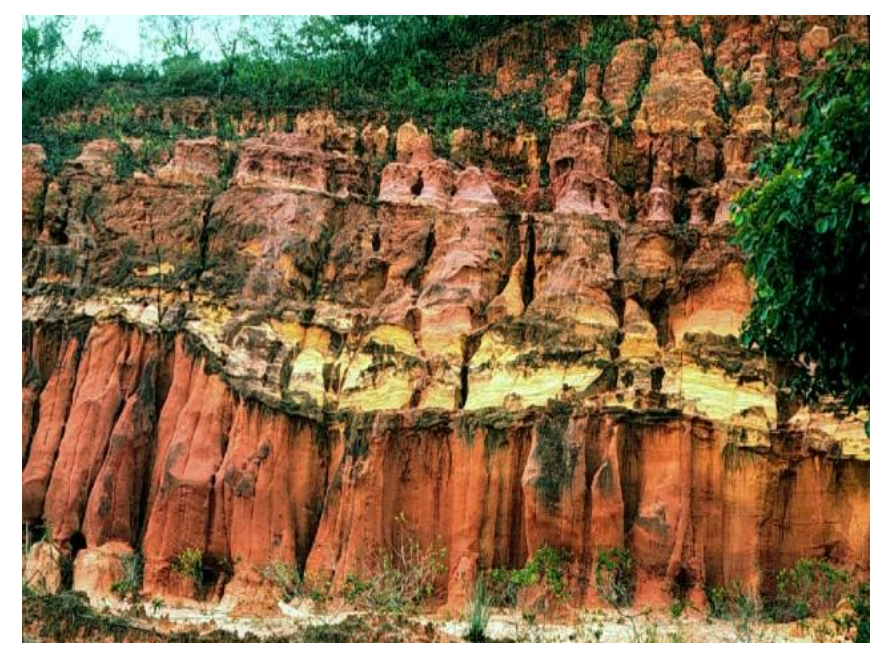

Fig. 7. Facies fluvial of the Buracica Stage. These facies are similars to the Aratu Stage. Note the flat erosional base. Campo de Araçás.

Another possibility, also found in Buracica Stage, in Recôncavo Basin, as well as in the Alagoas Basin and in the rift of Potiguar Basin, is the formation of a so-called flysch-like delta front. This situation corresponds to a fluvial-deltaic deposit where the bulk of the fluvial load deposits in lobes, not very deep, forming typical turbidite facies. Ponta da Sapoca, a place slightly north of the city of Salvador, is a typical example. 


\section{Prodelta}

Prodelta is the distal portion of the deltaic system. In marine environments, it is a place, still in the sea, where there is influence of fresh water, brought by rivers, extending up to tens of kilometers from the mouth in a lacustrine environment, even assuming a certain salinity of the water (hyposaline environment), as deduced as a function of increasing salinity upwards in the Buracica Stage (Della Fávera et al., 1994b). The blocky nature of Pojuca shales suggests a certain flocculation of clays in contact with salt water, not necessarily hypersaline, which could exist at that time.

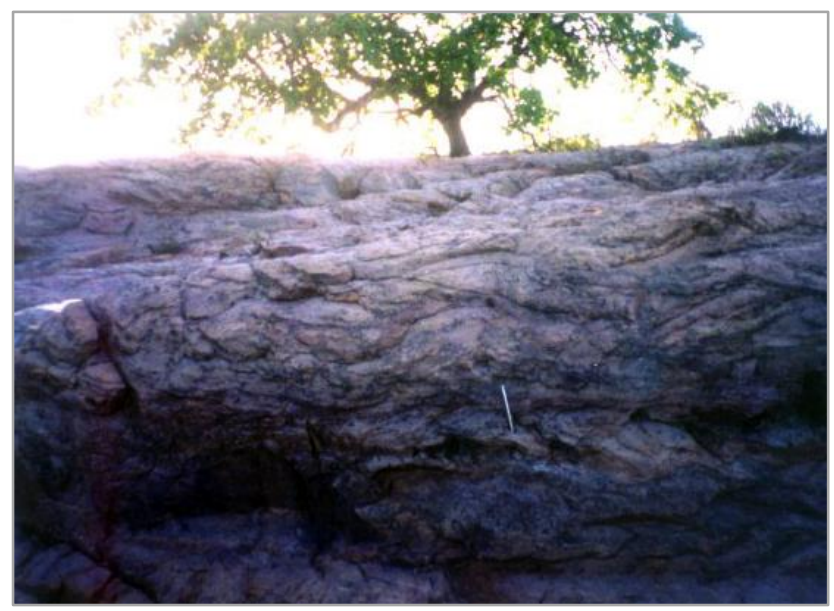

Fig. 8. Sigmoidal lobes. Frontal deltaic system. Sandstones of the Pojuca Formation. Aratu Stage. This is the only outcrop of this formation in the Recôncavo Basin. Highway Catu-Mata of São João, near the Mata de São João road, Bahia.

In Buracica Stage, Della Fávera (2001), mentioned the possibility of the existence of a "mobile lake" was as the final deposition environment. This situation is reported in the European Wealdian (Lower Cretaceous) and in the modern Niger River in the Sahel.

In South Africa, there is another similar situation, that of the Okavango Delta, where the Zambezi River simply ends in a swampy area. These marshy areas, which were associated with grasses (in the Lower Cretaceous, probably equisetal), appeared to have existed in the Recôncavo Basin, forming paleosols, similar to those found in Brazilian coal basins and indicated in the stratigraphic reference profile (Fig. 4). In some cases, they would correspond to the sedimentation found in the interdistributary bays of Mississippi-type deltas (Coleman and Gagliano, 1965), or to the modern swamps of the British Isles (Allen, 1981).

\subsubsection{The Lacustrine Environment}

Using the analogy of East African tectonic lakes, it is observed that they have a wide variety of contexts, from
RESEARCH PAPER

deep, freshwater lakes such as Tanganyika and Malawi to evaporitic basins such as Lake Natron.

In the present case, the Aratu Stage, two questions arise immediately. What is the depth of this lake? What is the highness of the lake level? There are no bathymetric indicators to establish the depth of the lake. The benthic biota, formed essentially by ostracods, is marginal, not exceeding $25 \mathrm{~m}$ deep. However, eventually, it is disseminated throughout the basin, indicating catastrophic re-sedimentation events. Although the entire Aratu Stage is considered to lie in a shallow lake context, it is quite possible that there were periodic elevations of ephemeral lake-level, the height of which would depend on the corresponding height of the rift's shoulders or the existence of effluents ("thieves") to other basins. Like the Buracica Stage (Della Fávera, 2001), these elevations would occur in times of climatic changes, after long periods of extreme aridity, producing catastrophic floods. It is believed that they could have reached high levels, since the petrophysical marker beds of the Recôncavo and its associated fauna can be correlated to thin levels of shale, separating thick sandy sections, in the Tucano and Jatobá basins.

Nor is there any information regarding the highness, unless the existence of a pine flora, which may correspond to the vegetation on the rift's shoulders.

\subsection{Growth Flows}

Growth flows are quite common in the studied interval. They exhibit variable displacement, around 20-30 $\mathrm{m}$, being quite characteristic in dipmeter profiles (growth of dip in "red" schemes). Its physical characteristics are reported in Della Fávera and Chaves (1998).

\subsection{Seismites}

A feature of the Pojuca Formation, in the Reconcavo Basin, as well as a good part of the Buracica Stage in this basin, is the occurrence of sandy sections bearing waterescape features (Fig. 8). These features range from convoluted folds, sedimentary breccias, to massive sandstones produced by total sediment homogenization.

The core from well 3-MG-99-BA, shown in Fig. 6, is a good example of this. According to Della Fávera (2001), these features are typical of seismites (Fig. 9), that is, sediments deformed by seismic shocks (faulting of the basin tectonic system, growth faults and lutokinetic movements). In a rift-type basin, seismicity is around 7 on the Richter scale, according to modern African examples. Deformed sediments were in quicksand situations, in the face of seismic shocks. The attribution of these features to landslides along a slope is erroneous, since almost the 


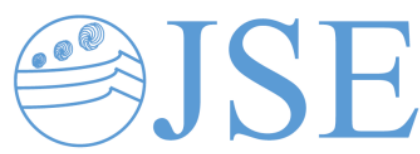

RESEARCH PAPER

entire section of the Pojuca Formation is affected by the deformations.

\subsection{The Taquipe Canyon}

In the SW of the Reconcavo Basin, there is a feature known as the Taquipe Canyon (Amorim, 1992). It is a submarine canyon, controlled by faults, originated near Marker 7. In the region, there is no correlation of the petrophysical marker beds as seen in the other portions of the basin. Within the canyon, there are deposits of subaquatic gravitational flows, such as turbidites, diamictites and slurry flows (homogeneities similar to those of the Pitanga Member of the Maracangalha Formation). In lithostratigraphic terms, they constitute the Taquipe Formation (not studied in this project). The Taquipe Canyon indicates the existence of deep waters in the portion of the basin where it occurs. It may have originated from a river process, at a low base level, followed by a simultaneous rise of the same level.

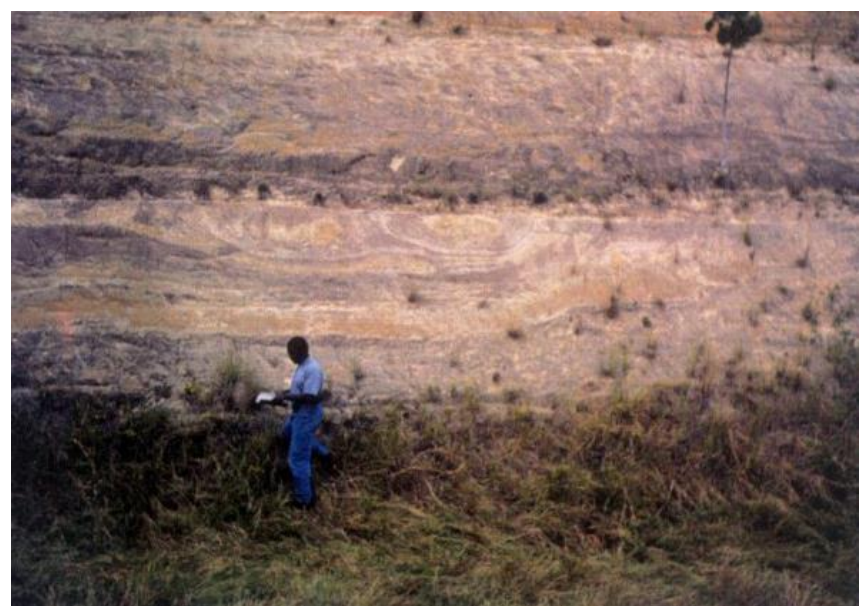

Fig. 9. Seismites (original facies probably sandstones with chanelled stratification). Buracic Stage, São Sebastião Formation. Highway BR-324, entrance to São Sebastião, Bahia.

\subsection{The Stratigraphic Meaning of Petrochemical Marker Beds}

Della Fávera (1987) established the meaning of the petrophysical marker beds. They constitute residual deposits (lags), formed during periodic elevations of the lake level (there are about 130 of these elevations in the Pojuca Formation), corresponding to Milankovitch orbital cycles.

They are condensed zones, due to the suppression of the sedimentary load of the rivers, arriving into the lakes. There is, in distal deposits, a relative enrichment of organic matter and other components of the biota, such as fish bones, ostracod shells, foraminifera tests and Thecamoebian remains. This material forms thin deposits of calciferous sandstones or shales. In the stratigraphic reference profile (Fig. 4), several of these levels can be visualized. Each corresponds to a shift of the SP curve to the right of the shale line, and to a peak in the resistivity curve. This response is similar to limestone. It is believed that the thickness of each condensed zone establishes the length of the peaks, and can then be related to events of higher or lower duration of the high lake phase. Depending on the length of the peaks, three orders of magnitude (fourth, fifth and sixth orders) were recognized.

\subsection{Stratigraphic Sections}

In order to correlate the depositional sequences observed in the area and to better understand their lateral behavior, five stratigraphic sections were analyzed: three from east to west and two from north to south.

The interval analyzed in this work comprises the sediments included between Marker 7 (top of section) and 11 (base of section). Among these landmarks, four more marker beds were identified: 8, 8A, 9, 9A. Marker 7 bed was established as the standard datum for correlating sections, since this is the highest marker bed identified in the area.

In section A-A' (Fig. 10) and its complementary section B-B' (Fig. 11), both with direction N-S, located in the western portion of the area, the presence of thick sand bodies stands out. The sand bodies become less expressive in the direction of the southern compartment of the basin. The characterization of the sedimentation of this section as "normal bell" and "inverted bel" patterns, respectively, indicates deltaic deposition, both systems of deltaic plain as deltaic front to prodelta (prograde).

The E-W sections (Fig. 12, 13 and 14) are characterized by the predominance of sand in the eastern part of the sections, due to sedimentary contribution from the Salvador Fault, which was active at that time. As the basin becomes deeper - mainly near the depocenters there is a predominance of clay sediments, as can be observed in sections C-C', D-D' and E-E', which represent diapiric movements in the larger phase of sedimentation in the basin.

\subsection{Stratigraphic Maps}

In order to define the behavior of the subsidence processes of the basin during its development, as well as to establish the direction of the source and the point of greatest concentration of coarse clastic material, stratigraphic maps of isopachs, isolites and sandstone percent were utilized.

Unfortunately, since no material was available, a structural map could not be drawn. This map would have shown the configuration of the basin after the rift phase, and the structural relationships with the presence of oil and gas fields in the region. 


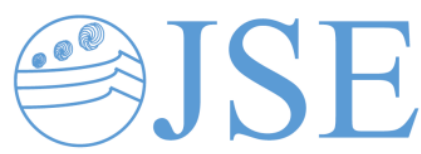

RESEARCH PAPER

The mapped intervals are between Marker 7 and 11 (Pojuca Formation). These were divided into three sedimentary cycles, separated by flooding surfaces (MFS), characterized by the presence of carbonate rocks at the top of each cycle.

The analysis of the general isopach map of the basin (Fig. 15) allows us to identify the eastern portion (near Salvador Fault) as the main depocenter. Subordinately individualized are two other depocenters, located in the S and NW portion of the basin.

It is observed that there is a higher concentration of sand in the NW, NE and SE portions, which becomes less expressive towards the center-south portion of the basin (Fig. 16). In this area, a large volume of diapiric shales (Candeias Formation) occurs.

This distribution of sediments is mainly due to the structural arrangement of the basin, which provides greater input of coarse material near the fault zones. This can be seen in the percentage of sandstone map (Fig. 17), where a sand distribution is observed from two main sources in the $\mathrm{N}$ and SE portions.

As previously mentioned, based on the major MFS, the studied range was divided into three cycles, Cycle 1, Cycle 2 and Cycle 3, which are characterized as follows:

Cycle 1. In this cycle, the depocenter of the basin coincides with the area of greatest sand thickness (Miranga Sandstone) and with the main source of distribution (eastern portion) (Fig. 18, 19 and 20).

Cycle 2. The basin has two main depocenters, in the $\mathrm{E}$ and W-NE portions, and a secondary one in the SW portion (Fig. 21). The sand bodies (Cambuqui 2 Sandstone) are distributed relatively parallel to the isopachs, being progressively less expressive towards the center-south portion of the basin. This suggests a main distribution source located in the N-NW portion (Fig. 22 and 23).

Cycle 3. In this cycle, the basin has two main depocenters: one located in the eastern portion (common to all three cycles) and another one located in the SW portion of the basin (Fig. 24). The sand bodies (Cambuqui 1 and Imbé sandstones) are concentrated in the $\mathrm{E}$ and $\mathrm{NE}$ portions, and at the interface of these areas, the sand bodies are thinner (Fig. 25). This also occurs towards the center-south portion of the basin (common to all three cycles).

The sandstone percent map shows that this cycle exhibits two main sources of distribution, with a spatial configuration similar to that of Cycle 2 , and to that of the source of distribution of the basin as a whole (Fig. 26).

\subsection{Analysis of Sedimentary Cyclicity}

The identification of possible sedimentary cycles in the studied section was achieved by spectral analysis of well 1-MDU-2-BA, which revealed results compatible with those obtained in previous analyses in the Buracica Stage, indicating that the climatic variations and lake level variations were the control processes for sediment contribution and sediment layer thickness. In addition, for a single well, the uniform tectonic effect of subsidence is considered as the main tectonic effect. Such conditions generated cyclic sedimentation, the product of an oscillatory process (Schwarzacher, 1993).

The periodogram obtained by spectral analysis (Fig. 27 ) shows the most important harmonics of numbers 76 , 69, 48, 28 and 15. Using the current procedure in LABCG, astronomical Milankovitch cycles are a possible explanation for the presence of cyclic sedimentation oscillations from $10 \mathrm{ka}$ to $100 \mathrm{ka}$ (Schwarzacher, 1993). Table 1 shows the values of orbital periods calculated for the Cretaceous (Berger et al., 1992). Comparing the average thickness (Table 2) with the periodicity of the Milankovitch cycles (Table 1), $19 \mathrm{ka}$ (precession) can be assumed as the elapsed time for the accumulation of cycles of $11.56 \mathrm{~m}$ (period of 6.32). Table 2 also shows the estimated duration for the major sedimentary cycles identified in the periodogram (Fig. 27). The above results indicate a period of $1.44 \mathrm{Ma}$ for total sedimentation of the studied interval.

Thus, an accumulation rate of $60 \mathrm{~cm} / 1000$ years is estimated, compatible with the results of this work. Table 2 also shows cycles of $21 \mathrm{ka}$ (precession), 30.72 and 51.57 (obliquity) and $96.27 \mathrm{ka}$ (eccentricity). The shorter cycles can be related to harmonics of shorter cycles, motivated by seasonal climatic variations, known as important factors of cyclic sedimentation in rift basins.

The behavior of sedimentation over time was also analyzed in a complementary way with the graphs of the accumulated deviations of the mean thickness (Fischer's graph) of well 1-MDU-2-BA, using 480 cycles with 1.83 $\mathrm{m}$ average thickness. This graph shows a transgressive sedimentation at the base that extends to frame 7 at the top (Fig. 28).

\subsection{Petroleum Geology - Reservoir and Source Rock Facts}

The main oil fields in the basin that produce in the studied interval are the Taquipe, Miranga, Miranga Norte, Fazenda Panelas, Imbé and Araçás fields. But there are traces of oil in other areas.

The accumulation of hydrocarbons in this region is associated with dome structures, most of them cut by longitudinal faults oriented according to NE and NW directions. In the case of Miranga field, the main structure is formed by a residual anticline, genetically associated with shale moved by diapirs that occurred during the deposition of the Pojuca Formation. 
RESEARCH PAPER

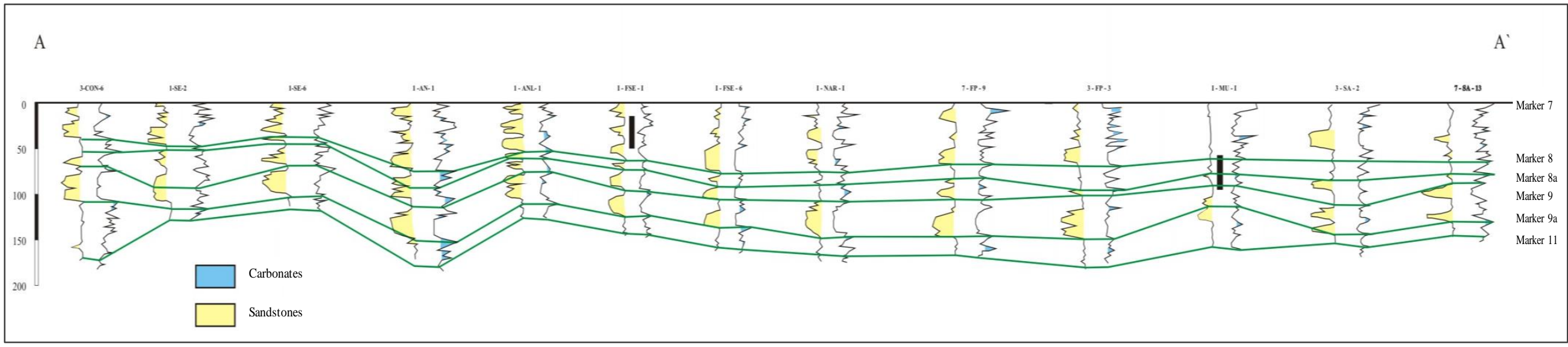

Fig. 10. Stratigraphic section A-A'.

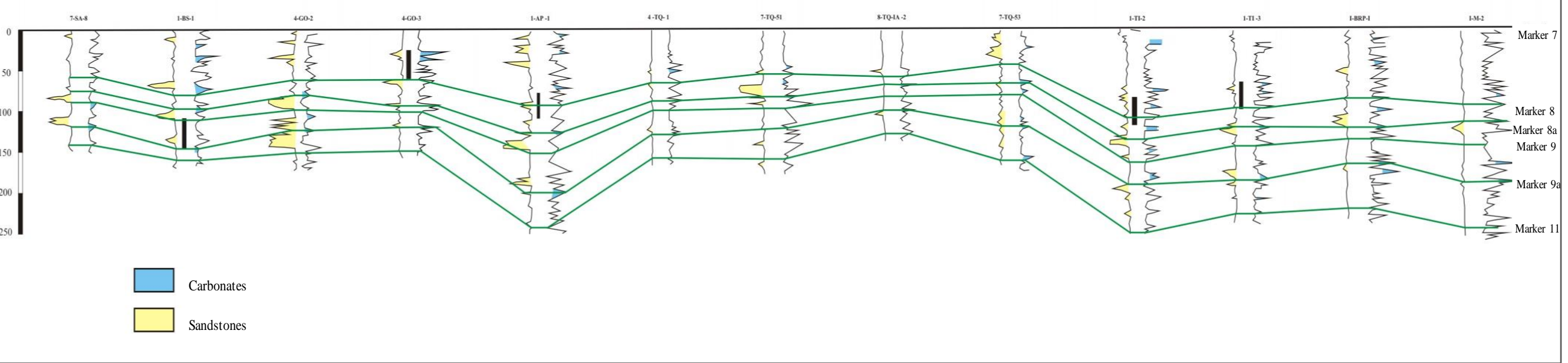

Fig. 11. Stratigraphic section B-B'. 
RESEARCH PAPER

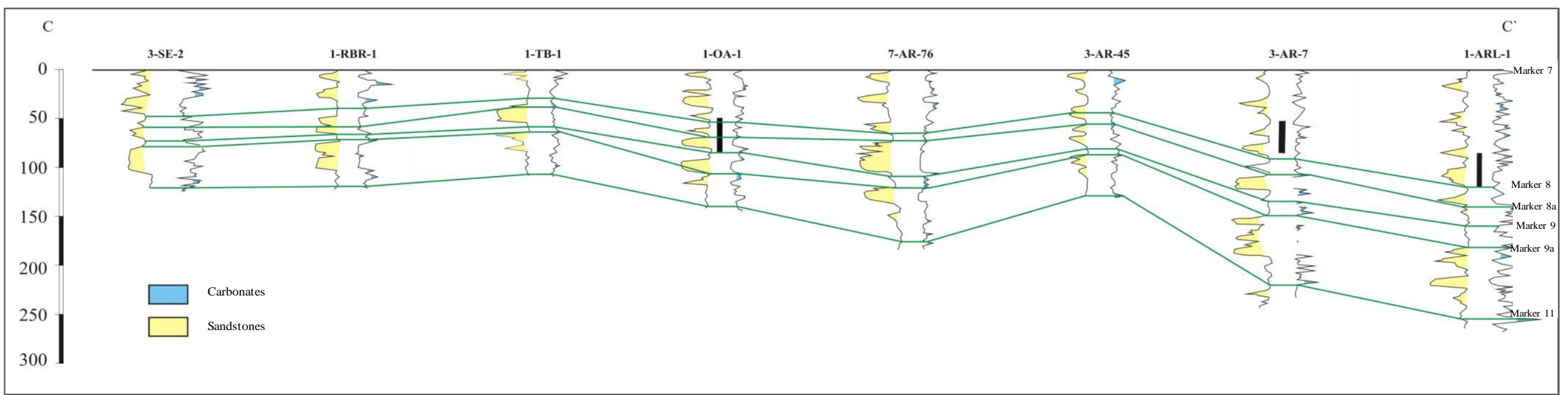

Fig. 12. Stratigraphic section C-C'.

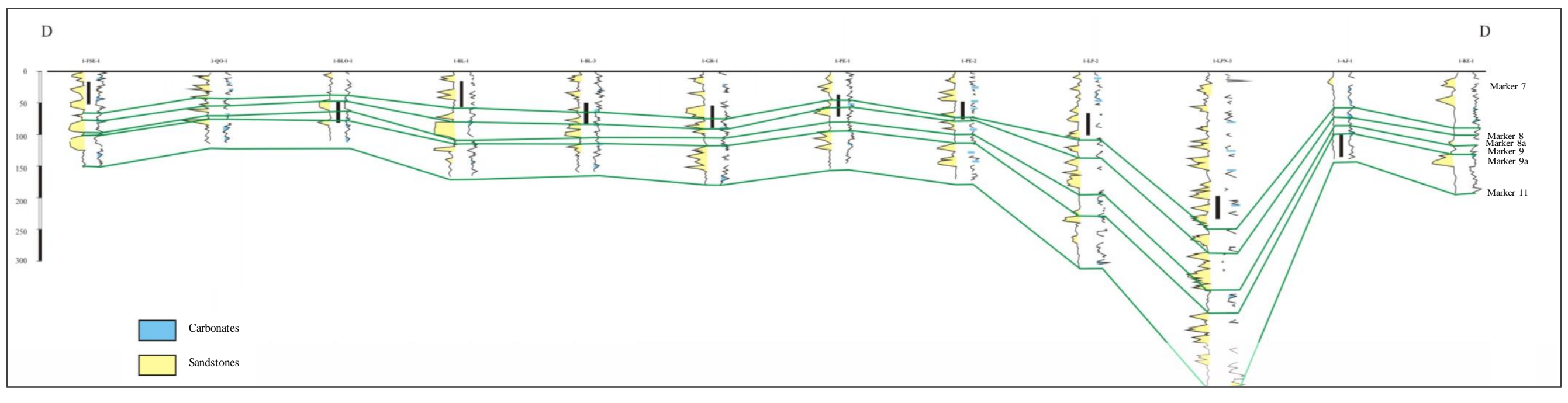


Fig. 13. Stratigraphic section D-D'.

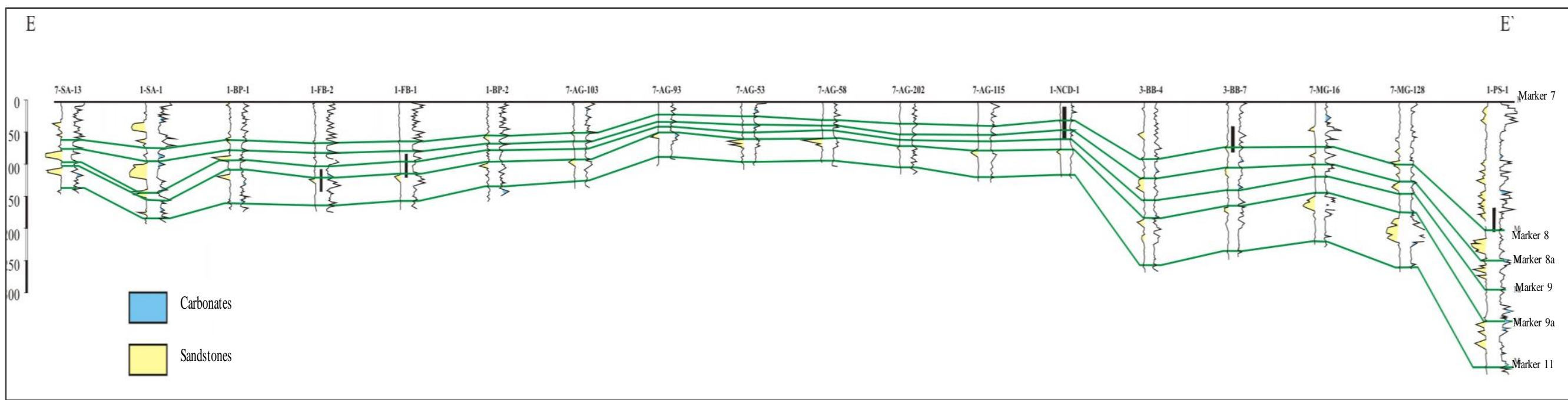

Fig. 14. Stratigraphic section E-E'.

Tab. 1. - Milankovitch orbital cycles for the Cretaceous, and ratios for the $19 \mathrm{ka}$ cycle (Berger et al., 1992).

\begin{tabular}{l|ccccccccc}
\multicolumn{3}{c}{ Eccentricity } & \multicolumn{4}{c}{ Obliquity } & \multicolumn{3}{c}{ Precession } \\
\hline $\begin{array}{l}\text { Cycles } \\
\text { (ka) }\end{array}$ & 400.0 & 100.0 & 95.0 & 43.0 & 41.0 & 29.0 & 23.0 & 21.7 & 19.0 \\
rates & 21.05 & 5.26 & 5.0 & 2.26 & 2.16 & 1.53 & 1.21 & 1.14 & 1.00
\end{tabular}

Tab. 2. Relationship between periods and age estimates

\begin{tabular}{l|llll} 
Harmonics & Period & Rate & Thickness (m) & Age (ka) \\
\hline $\mathbf{1 5}$ & 32.00 & 5.07 & 58.36 & 96.27 \\
$\mathbf{2 8}$ & 17.14 & 2.71 & 31.37 & 51.57 \\
$\mathbf{4 7}$ & 10.21 & 1.62 & 18.69 & 30.72 \\
$\mathbf{6 9}$ & 6.96 & 1.10 & 12.73 & 20.93 \\
$\mathbf{7 6}$ & 6.32 & 1 & 11.56 & 19.00
\end{tabular}



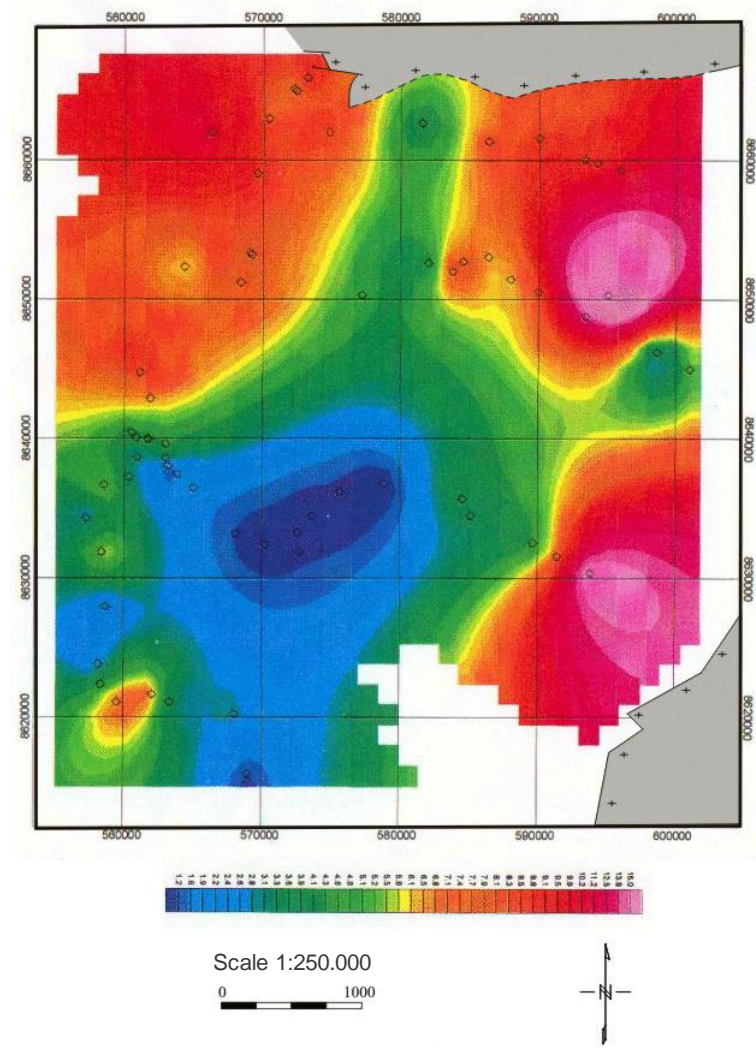

Fig. 15. Isolith Map of the interval 7-11.

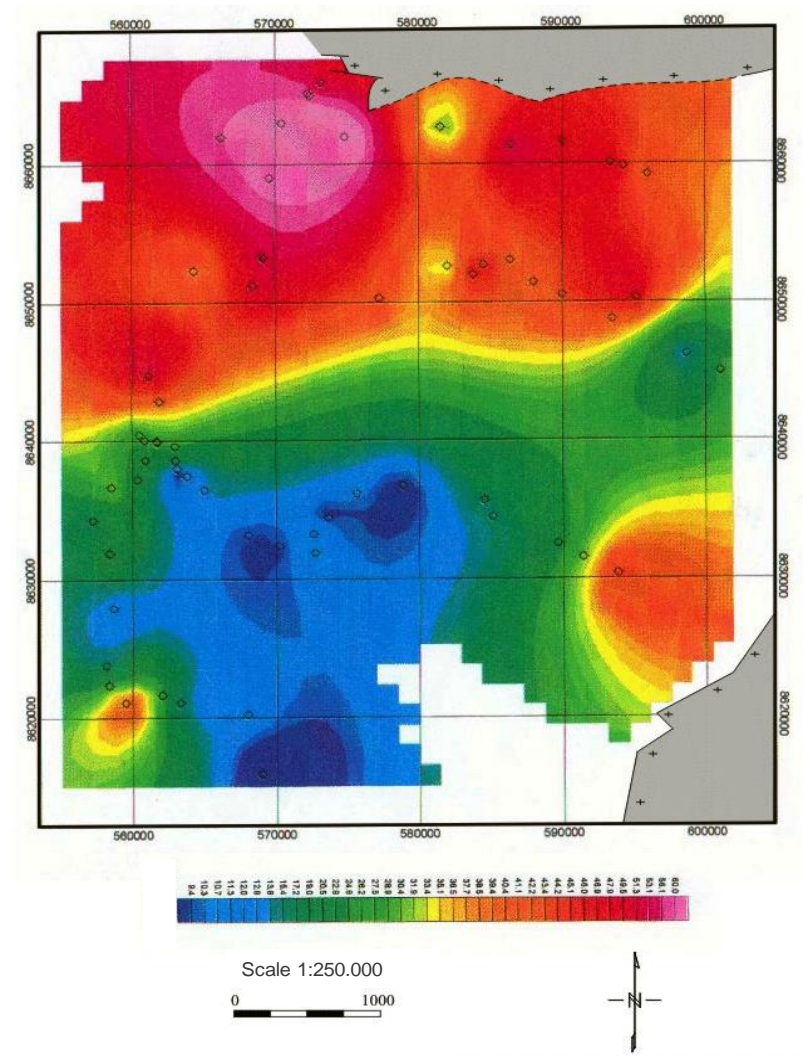

Fig. 17. Map of distribution Sand (\%) of the interval 7-11.
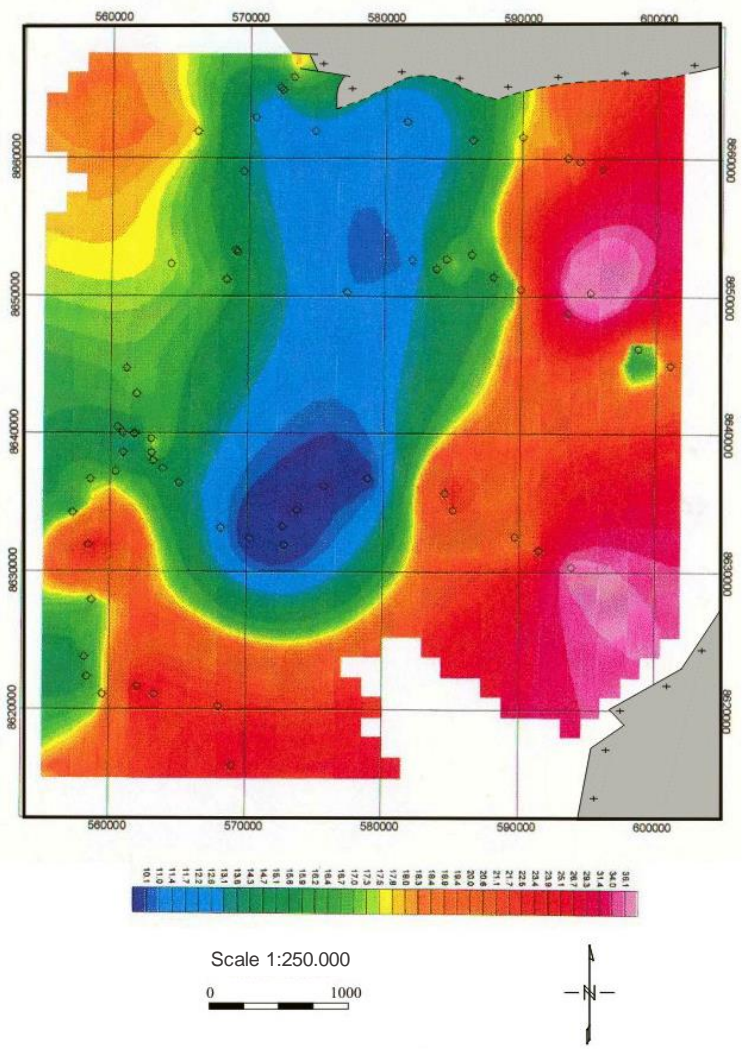

Fig. 16. Isopach map of the interval 7-11.

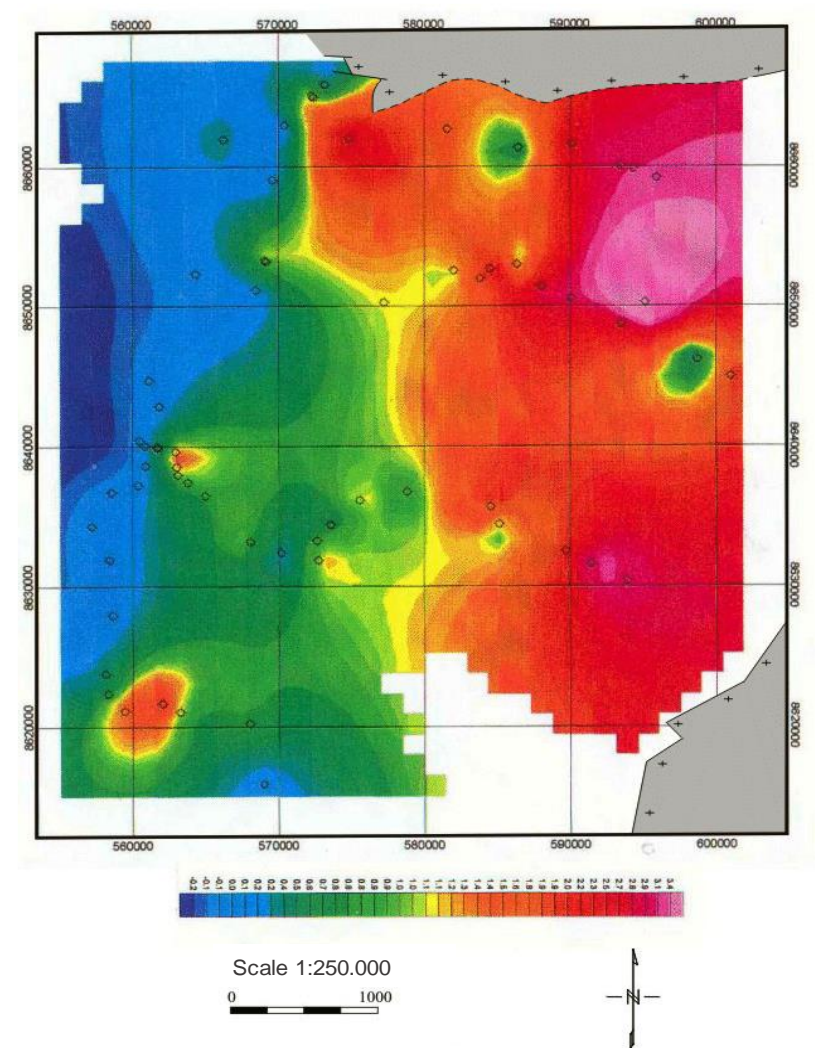

Fig. 18. Isolith map of the interval 11-9A. 


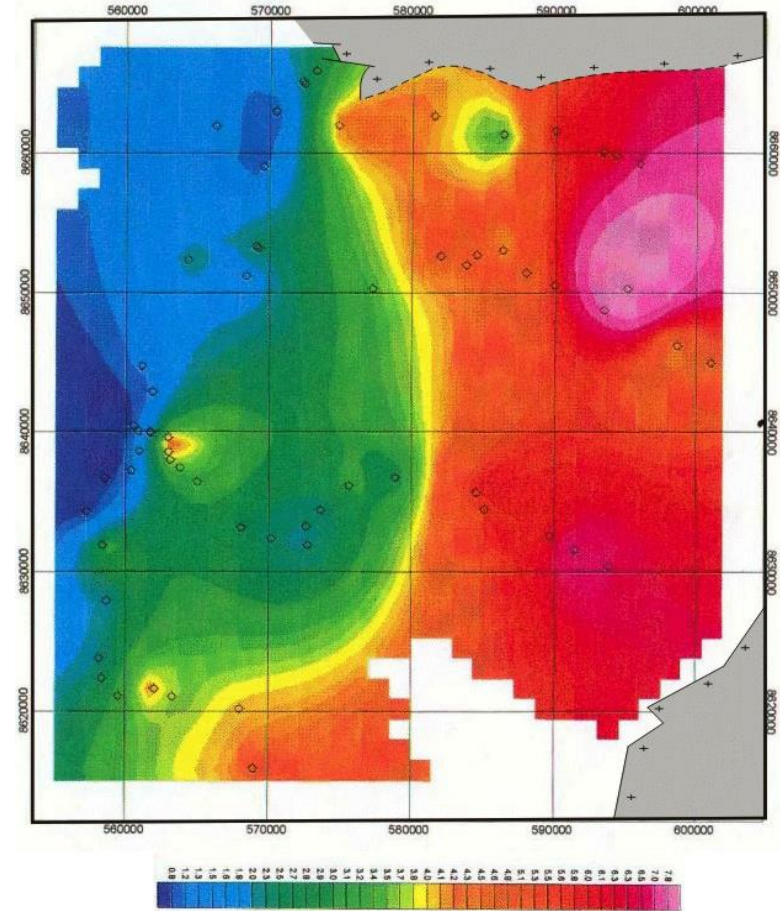

\section{Scale 1:250.000}

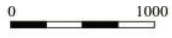

Fig. 19. Isopach map of the interval 11-9A.
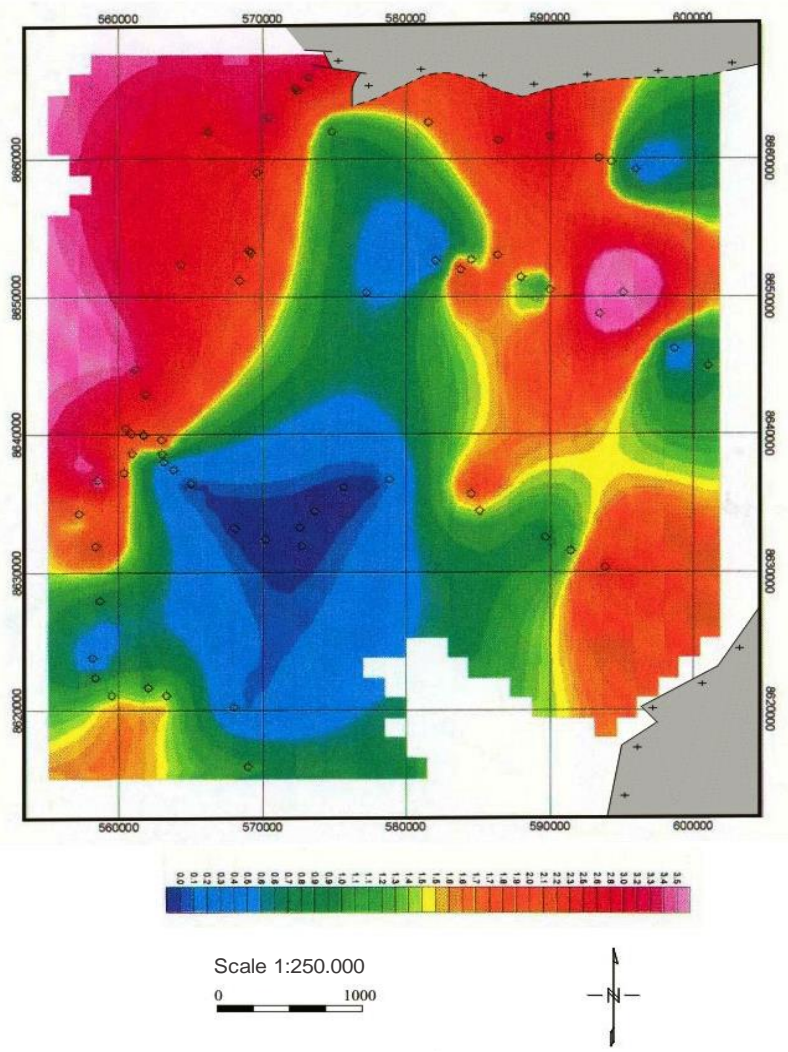

Fig. 21. Isolith map of the interval 9A-8A.

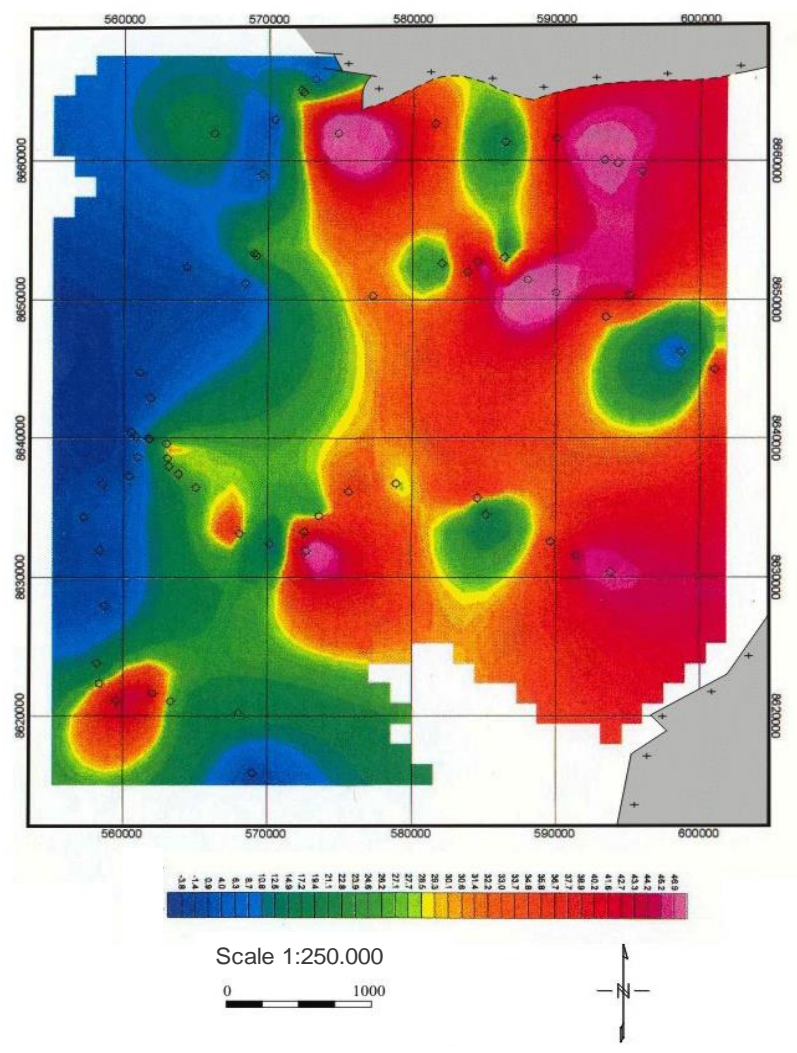

Fig. 20. Map of distribution of sand (\%) of the interval 11-9A.
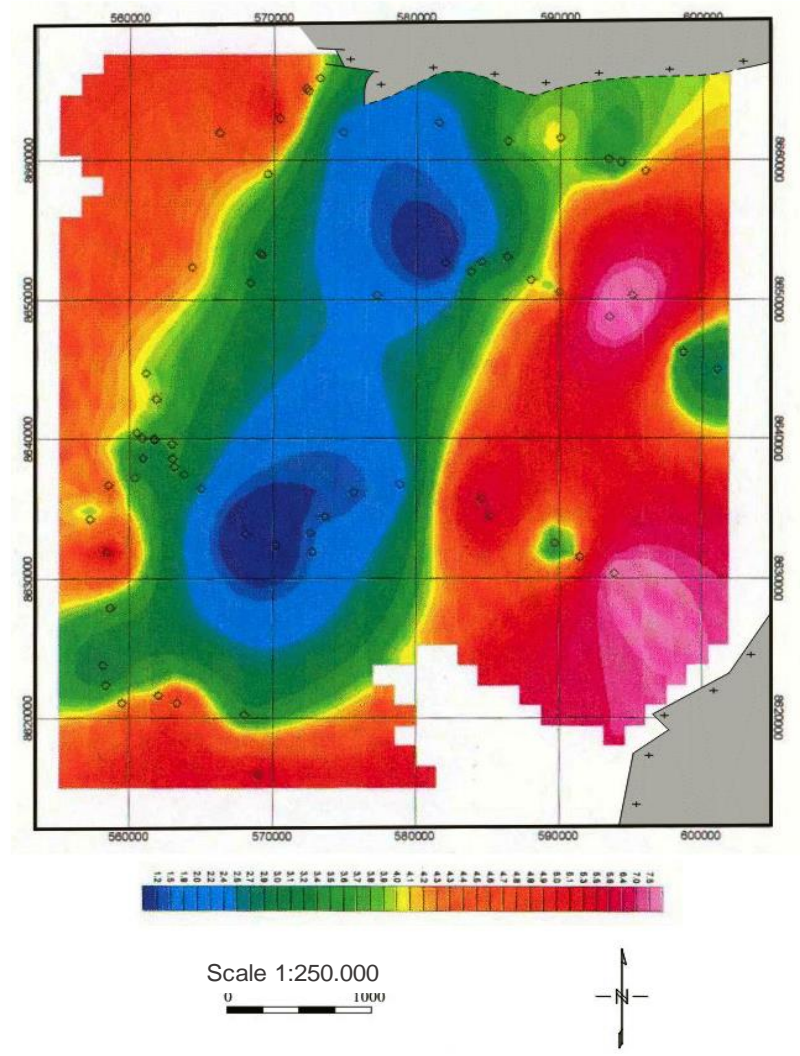

Fig. 22. Isopach map of the interval 9A-8A. 


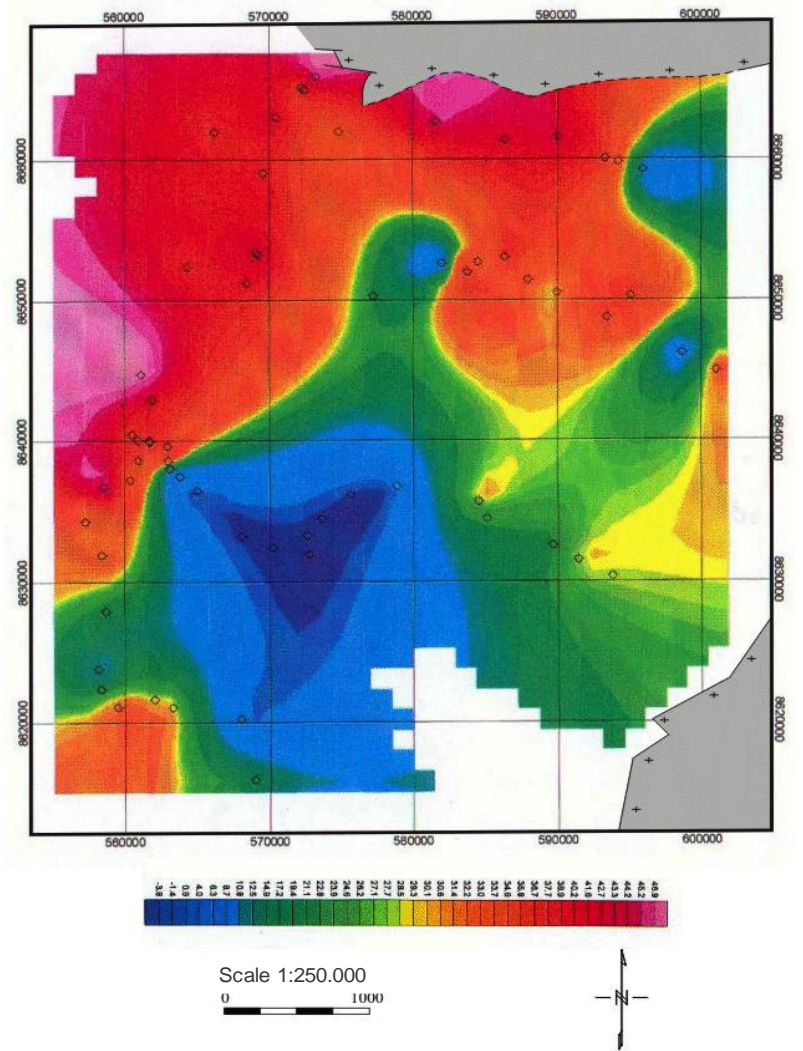

Fig. 23. Map of distribution of sand (\%) of the interval 9A-8A
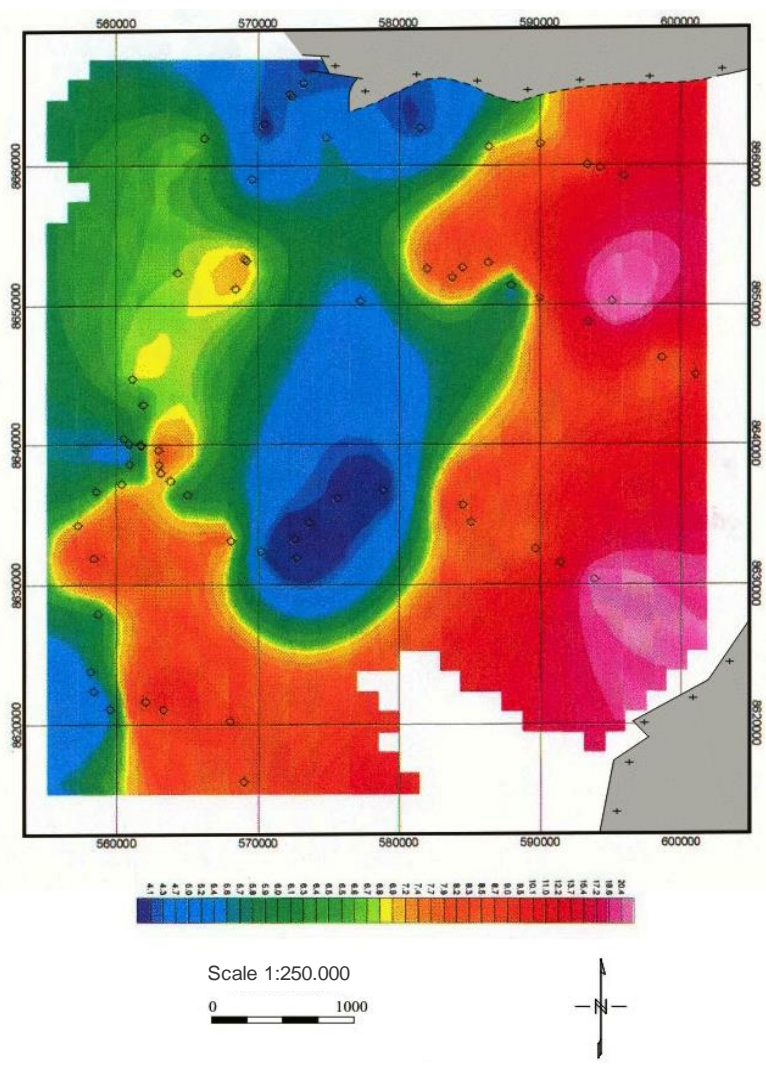

Fig. 25. Isopach map of the interval 7-8A.

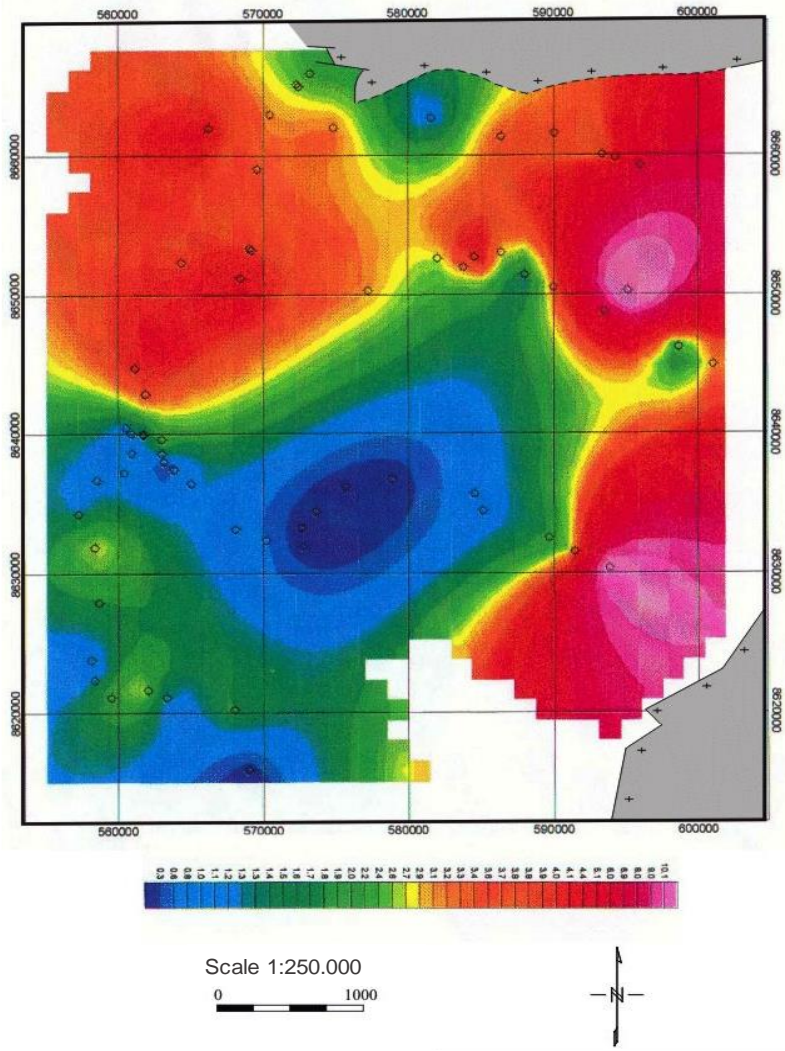

Fig. 24. Isolith map of the interval 7-8A.
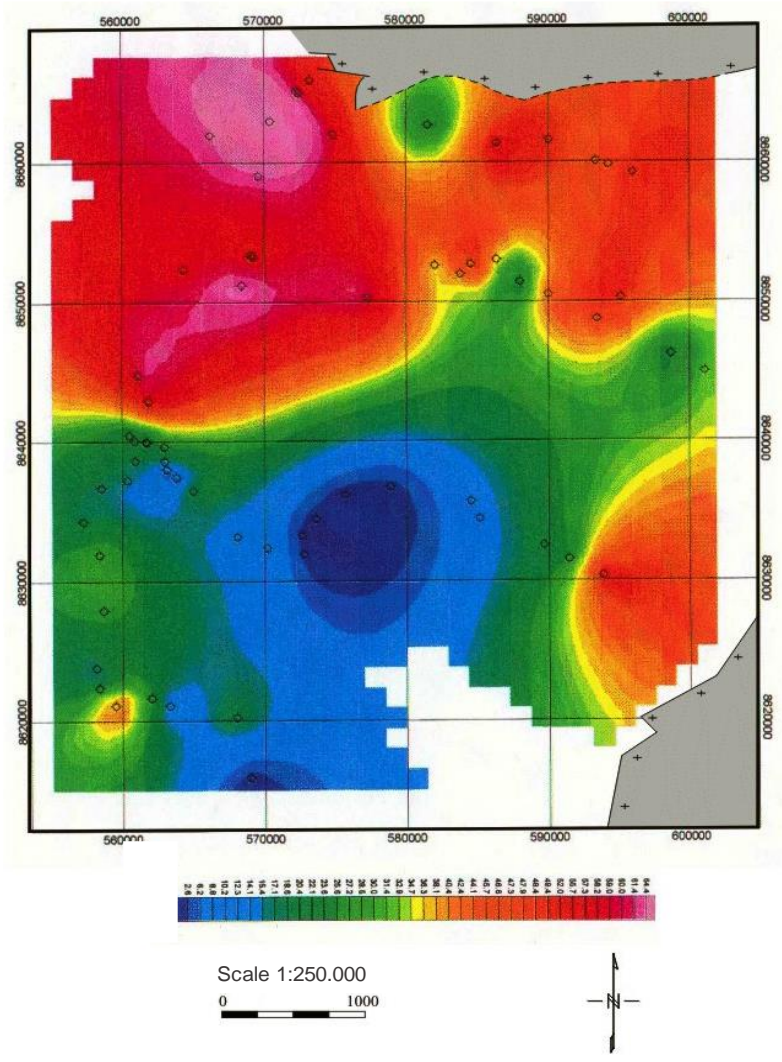

Fig. 26. Map of distribution of sand (\%) of the interval 7-8A. 
It is noteworthy that production comes from both structural traps, as in Miranga, Araçás, Panelas and Imbé, as well as from stratigraphic-structural traps, as in Taquipe and some Miranga sands.

These traps are formed by prodeltaic shales, which were deposited in large transgressive intervals, capping the sandstones related to the regressive phases of deltaic progradation. In environments favorable to developing this arrangement, vertical entrapment of hydrocarbons, allied with fast burial, is essential for the generation and conservation of hydrocarbons.

Regressive cycles provided shales and regional shaleout of sandstones, allowing stratigraphic trapping only where the environment was favorable to generation.

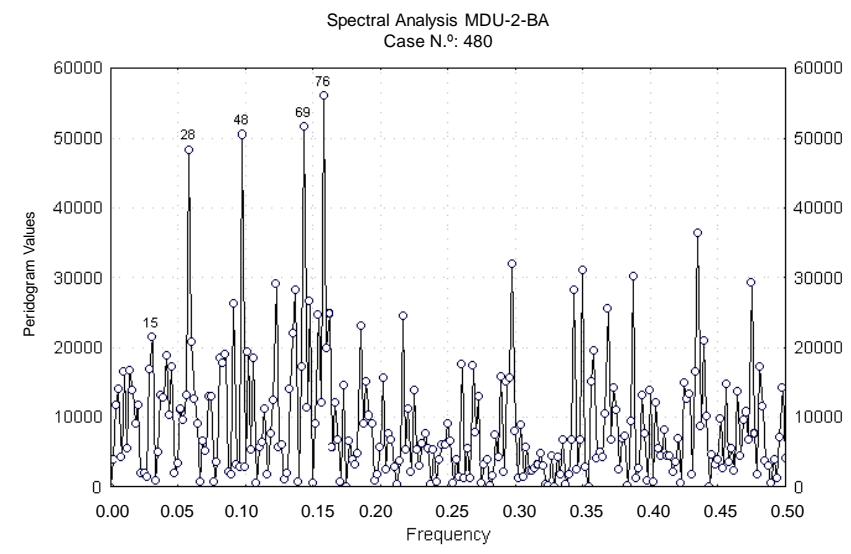

Fig. 27. The periodogram obtained by spectral analysis showing the most important harmonics of numbers 76, 69, 48, 28 and 15 .

The reservoir sandstones are related to delta front and lower delta plain environments. They exhibit coarsening upwards, fine to very fine granulometry, and sandstones with medium granulometry are observed, with rare coarse aggregate levels. They have color ranging from gray to light ash, calciferous cement and clay matrix, and good porosity and permeability (unfortunately, these data are not available in this work).

In terms of source rocks in the studied interval, the Candeias Formation includes in more detail the Tauá and Gomo Members, both of which are generators of oil in the Recôncavo Basin. The Tauá Member, in the basal portion, is characterized by dark gray, fissile, acicular partition shales, rich in organic matter, frankly lacustrine and finely laminated. The Gomo Member is composed of thick greenish gray shales, but, intercalated with biocalcarites, calcilutites and turbiditic sandstones, in a deep lake system.

These rocks are characterized by an average total residual carbon content (TOC) of $1 \%$ and an approximate residual potential of $5 \mathrm{Kg} \mathrm{HC} / \mathrm{t}$, reaching values around $10 \mathrm{Kg} \mathrm{HC} / \mathrm{t}$.
RESEARCH PAPER

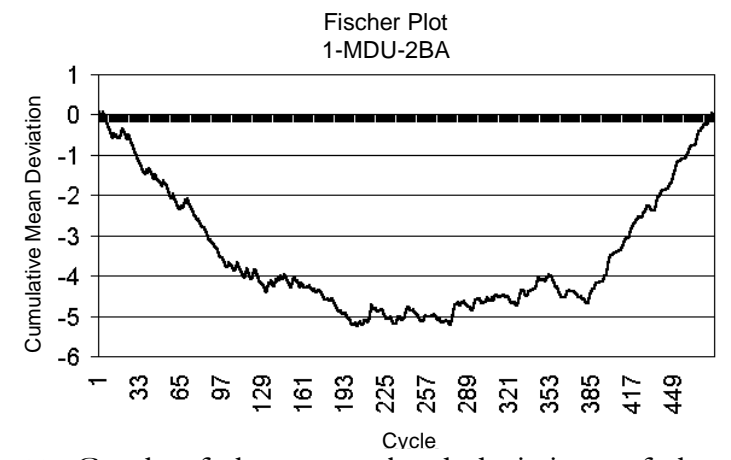

Fig. 28. Graph of the accumulated deviations of the mean thickness (Fischer's graph) of well 1-MDU-2-BA, using 480 cycles with $1.83 \mathrm{~m}$ average thickness.

As evidenced in the isolithic and isopach maps, significant hydrocarbon occurrences in the studied interval occur in areas with a marked sedimentation rate, located within deltaic and lower deltaic environments, and where structuring and/or shale-out of sandstones occur. As a curiosity, it is observed that oil does not occur in sections with a percentage of sandstone greater than $30 \%$.

Thus, the observed reservoir sandstones present possibilities for new deposits, and exhibit conditions for structural stratigraphic traps in belts of pinching out and shale gradation, located in high subsidence regions, in deltaic environments of delta front and/or contiguous lower delta plain.

\section{Conclusion}

The studied interval, as well as the entire Pojuca Formation, exhibits a section of a river dominated delta, in which, using information from the SP profile and from well cores, it is possible to separate several associations of facies, from fluvial to prodelta. It was observed that most of the sandy sediments are deformed by water leakage phenomena generated by seismic shocks (seismites).

The maps and stratigraphic sections reflect this deltaic system, in the sense that they show a lateral variation of the sandstone content, indicating a source located N-NW, and the most distal, perhaps deeper, to the S and SE.

The Aratu Stage presents a remarkable sedimentary cyclicity with cycles reflected in the SP and resistivity profiles, in which self-correlation can be done. The control of this cyclicity should have been established by earth orbital movements of the precession type, obliquity, and, subordinately, eccentricity. The estimated sedimentation rate was approximately $60 \mathrm{~cm} / 1000$ years, lasting throughout the studied interval of 1.44 million years.

Based on the occurrence of transgressive lags, which translate into the profiles as sharp peaks, whose ohmic 
value is a function of their thickness, we can divide the section into cycles of third- to sixth- orders of magnitude.

We would like to suggest to the National Petroleum Agency (ANP) a modification in its policy of distribution of data to universities. At present, it is very difficult, especially for public universities, to obtain data from that agency. In the present case, this project was only possible because its coordinator had, in his personal archive, material from the time he was part of Petrobras' technical staff, such as copies of profiles, photographs and descriptions of well-cores, in addition to material provided by Paulo Horschutz, mentioned above.

\section{Acknowledgements}

This work is a contribution of the tenth Course in Basin Analysis Projects (CPAB) and the Laboratory of Basin Analysis and Geological Correlation (LABCG) of the State University of Rio de Janeiro. The authors are grateful to Geologist Paulo Márcio C. Horschutz, an independent consultant, for having provided the material of his work, which made possible the accomplishment of this work. The authors also would like to thank all the people who give support to this work. Virginia Martins would like to thank the Conselho Nacional de Desenvolvimento Científico e Tecnológico of Brazil (CnPQ) by the research grant (reference number: 301588/2016-3)

\section{References}

Allen, P., 1981. Pursuit of Wealden Models. Journal of the Geological Society $138 \quad$ (4), 375-405. https://doi.org/10.1144/gsigs.138.4.0375

Amorim, J.L., 1992. Evolução do preenchimento do Cânion de Taquipe sob o enfoque da estratigrafia moderna. MsD Thesis, Universidade Federal do Rio Grande do Sul, UFRGS, Porto Alegre.

Asmus, H. E., Ponte F. C., 1973. The Brazilian marginal Basin. In Nairn A. E. M. and Stelhi F. G. (orgs), The Ocean Basins and Margins, v. 1, South Atlantic. New-York, London: Plenum Press, 87-132.

Asmus, H. E., Porto R., 1980. Diferenças nos estjgios iniciais da evolução da margem continental brasileira: possíveis causas e irnplicaçöes. Anais do XXXI Congresso Brasileiro de Geologia 1, 255-239.

Berger, A., Loutre, M.F., Laskar, J. 1992. Stability of the Astronomical frequencies over the earth's history for paleoclimate studies. Science 225, p. 560-566. https://doi.org/10.1126/science.255.5044.560

Bozhko, N. A., 2009. Supercontinental Cyclicity in the Earth's Evolution. Moscow University Geology Bulletin, 2009, Vol. 64, No. 2, pp. 75-91. Allerton Press, Inc.

Caixeta, J.M., Gilmar, V.B., Magnavita, L.P., Feijó, F.J., 1994. Bacias do Reconcavo, Tucano e Jatobá, Boletim de Geociências da Petrobras, 8 81), 163-172.

Coleman, J.M., Gagliano, S.M. 1965. Sedimentary structures: Mississippi River Deltaic Plain. In: Primary Sedimentary Structures and their Hydrodynamic Interpretation.

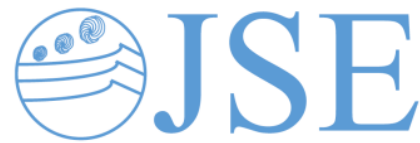

RESEARCH PAPER

$\begin{array}{llll}\text { S.E.P.M., } & \text { Spec. } & \text { Publ. } & 12,\end{array}$ https://doi.org/10.2110/pec.65.08

Della Fávera, J. C., Chaves, C., 1998. Growth-faults in the Depositional Setting of Gondwanic Coal, Paraná Basin, Brazil. Anais da Academia Brasileira de Ciências 70 (3), 453463,

Della Fávera, J. C., Chaves, H. A. F., Pereira, E., Bergamaschi, S., Reis, C. C. Lima Fo., M. F., Pereira, S. D., 1993. Geologia da Área de Figueira-Sapopema, Bacia do Paraná, Estado do Paraná. LABCG/UERJ. Relatório final do $2^{\circ}$ Curso de Análise de Bacias, Rio de Janeiro, 89 p.

Della Fávera, J.C., 2001. Fundamentos da Estratigrafia Moderna. Rio de Janeiro, UERJ, 264 p.

Della Favera, J.C., Castro, J.C., Soares, U.M., Rosetti, E.L., Azambuja, N.C., Rodrigues, R., Hashimoto, A.T., Matsuda, N., Guzzo, J., Alves, D.B., 1994a. Estratigrafia de Seqüências da Formação Pendência, Bacia Potiguar. $3^{\circ}$ Simpósio sobre o Cretáceo do Brasil, Rio Claro (Abstract).

Della Fávera, J.C., Chaves, H.A.F., Medeiros, M.A.M., Meneses, C.P. Tavares, M.E.A., González, M.E., Pinheiro, M.L.D., Silva, O.C., 1994b. Análise Estratigráfica do Andar Buracica, Bacia do Recôncavo. Monography, "3 Curso de Projetos de Análise de Bacias", Universidade do Estado do Rio de Janeiro (UERJ), Faculdade de Geologia, Brasil, 93 p.

Della Fávera, J.C.D., 1987. Natureza e significado estratigráfico dos marcos elétricos na seção do Andar Aratu, bacia do Recôncavo: Tenth Congresso Brasileiro de Paleontologia, Resumo das Comunicações, Rio de Janeiro, p. 72.

Fernandes Filho, J.A., Muricy Filho, A.F., Silva, O.B., Zabalaga, H.M.C., 1982. Estágio atual da exploração do petróleo da Bacia do Recôncavo. Anais XXXII Congresso Brasileiro Geologia 5, 2273 -2285.

Ferreira, T.S., deAraújo, M.N.C., da Silva; F.C.A., 2014. Cenozoic folding in the Cumuruxatiba basin, Brazil: An approach to the deformation trigger by the Abrolhos magmatism. Marine and Petroleum Geology 54, 47-64.

Figueiredo, A.M.F., J.A.E. Braga, J.C. Zabalaga, J.J. Oliveira, G.A. Aguiar, O.B. Silva, L.F. Mato, L.M.F. Daniel, L.P. Magnavita, and C.H.L. Bruhn, 1994, Recôncavo Basin, Brazil: a prolific intra-continental rift basin, in S.M. Landon (ed.), Interior rift basins: AAPG, Tulsa, Oklahoma, USA, Memoir 59, p. 157-203.

Galloway, W.E., 1989. Genetic Stratigraphic Sequences in Basin Analysis I: Architecture and Genesis of Flooding-Surface Bounded Depositional Units. The American Association of Petroleum Geologists Bulletin, 73 (2), pp. 125-142, 11 Figs. DOI:10.1306/703C9AF5-1707-11D7-8645000102C1865D

Gordon, A., Destro, N., Heilbron, M., 2017. The RecôncavoTucano-Jatobá Rift and Associated Atlantic Continental Margin Basins. M. Heilbron et al. (eds.), São Francisco Craton, Eastern Brazil, Regional Geology Reviews, (C) Springer International Publishing Switzerland. DOI 10.1007/978-3-319-01715-0_9

Gregory, J.W., 1896, The Great Rift Valley: London, John Murray, 424pp.

Gregory, J.W., 1921, Rift Valleys and the Geology of East Africa: London, Seeley Service, 479pp.

Horschutz, P., Della Fávera, J.C., Passos, L.J., 1973. Sedimentação Deltaica da Seqüência Cambuqui, Formação 
Pojuca, Bacia do Recôncavo. Anais do XXVII Congresso Brasileiro de Geologia, Aracaju, pp. 315-338.

Klein, G. de V., de Melo, U., Della Fávera, J.C., 1972. Subaqueous gravity processes on the front of Cretaceous Deltas, Reconcavo Basin, Brazil. Geological Society of America Bulletin 83, 1468-1482. DOI: 10.1130/00167606(1972)83[1469:SGPOTF]2.0.CO,2

Magnavita, L.P., da Silva, R.R., Sanches, C.P., 2005. Guia de Campo da Bacia do Recôncavo, NE do Brasil. Field trip guide of the Recôncavo basin, NE Brazil. Roteiros geologicos. Buletim de Geociências da Petrobras, Rio de Janeiro 13 (2), 301-334.

Milani, E.J., 1987. Aspectos da evolução das bacias do Recôncavo e Tucano Sul, Bahia, Brazil. Petrobrás, CENPES, Rio de Janeiro, sec. explor. Petróleo, no 18, 61 p.

Picarelli, A., Abreu, V., 2012. Sequence stratigraphy applied to continental Rift Basins: Example from Recôncavo Basin, Brazil, in O. W. Baganz, Y. Bartov, K. Bohacs, and D. Nummedal, eds., Lacustrine sandstone reservoirs and hydrocarbon systems: AAPG Memoir 95, p. 347-366.

Ponte, F.C., Northfleet, A.A., Gonçalves, A., et al., 1971. A. Evolução paleogeográfica do Brasil Oriental e Africa Ocidental. Petrobrás Internal Report.

Potter, P.E., Ferreira, A.M.C., Cruz, C.E.S., Abreu, C.J., Gonzaga, G.M., Dias, J.L., Diniz, M.N., Meneses, S.X., 1977. Projeto São Sebastião: deposição flúvio-lacustre nos andares Buracica/Jiquiá. Rio de Janeiro: PETROBRAS. DEXPRO, 36 p. Internal Report.

Rossetti, E.L., 1996. Estratigrafia de Seqüências de alta resolução obtida com imageamento de linhas sísmicas na fase rifte da Bacia Potiguar (Eo-Cretáceo). MsD Thesis, Porto Alegre: Universidade Federal do Rio Grande do Sul, 151 p.
RESEARCH PAPER

Saitta-Bertoni, S., Visher, G.S., 1968. Subsurface study of the southern portion of the Bluejacket Delta. In: Geology of the Bluejacket-Bartlesville Sanstone, Oklahoma City, Geol. Soc., Guidebook, pp. 52-68.

Schwarzacher, W., 1993. Cyclostratigraphy and the Milankovitch theory. 1st Edition, Developments in Sedimentology, Elsevier Science, Amsterdam. 52, 225 p.

Silva, H.T. da, 1993. Flooding Surfaces, Depositional Elements and Accumulations rates - Characteristics of the Lower Cretaceous Tectonosequence in the Recônavo Basin, Northeast Brazil. PhD Thesis, University of Texas, Austin, Texas, USA, $310 \mathrm{p}$.

Soares, U.M., Rossetti, E.L., 2005. Tectonismo e sedimentação na porção SW do Rifte Potiguar - Bacia Potiguar emersa. Boletim de Geociências da Petrobras, 13(2), 149-166.

Vail, P.R., 1987. Seismic stratigraphy interpretation using sequence stratigraphy, part I, seismic stratigraphy interpretation procedure. In: A. W. Bally, ed., Atlas of Seismic Stratigraphy, v. 1: AAPG Studies in Geology 27, pp. 1-10.

Vail, P.R., Audemard, F., Bowman, S.A., Eisner P.N., PerezCruz C., 1991. The stratigraphic signatures of tectonics, eustasy and sedimentology - an overview. In: Einsele, G., Ricken W. and A. Seilacher (eds.): Cycles and events in stratigraphy. - Springer-Verlag, Heidelberg, 617-659.

Van Wagoner, J. C., R. M. Mitchum, Jr., H. W. Posamentier, and P.R. Vail, 1987, Seismic stratigraphy interpretation using sequence stratigraphy, part 2, key definitions of sequence stratigraphy. In A. W. Bally, ed., Atlas of seismic stratigraphy, v. 1: AAPG Studies in Geology 27, p. 11-14. 